El protagonismo de las mujeres en el Imperio Romano. Del politeísmo tradicional al monoteísmo cristiano Juana Torres

Anuario № 31 / ISSN 1853-8835 / 2019

http://anuariodehistoria.unr.edu.ar/ojs/index.php/Anuario/index

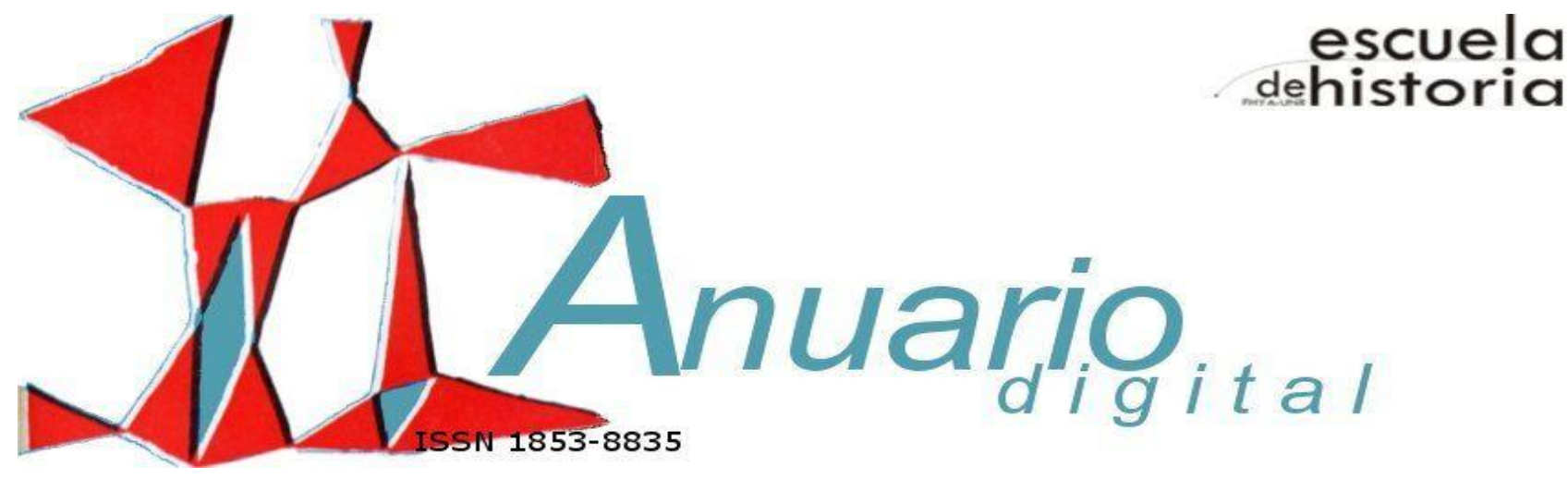

\title{
El protagonismo de las mujeres en el Imperio romano. Del politeísmo tradicional al monoteísmo cristiano
}

\section{Female protagonism in the Roman Empire. From traditional Polytheism to Christian monotheism}

JUANA TORRES

(Universidad de Cantabria); España

torresj@unican.es

RESUMEN

En este capítulo se lleva a cabo un recorrido por la historia de las mujeres en el Imperio romano, es decir, en los cuatro primeros siglos de nuestra era. Uno de los aspectos insoslayables para llevar a cabo ese objetivo tiene que ver con la religión predominante en cada momento, pues en cualquier sociedad ha existido siempre un conjunto de creencias religiosas, que ha condicionado la existencia de los individuos. La información sobre la condición femenina procede fundamentalmente de los textos de los hombres, a partir de los cuales se ha reconstruido su vida. Por ellos sabemos que las mujeres estuvieron oficialmente excluidas de la política y de la vida pública, y también relegadas en el ámbito religioso, ya que los civilia officia eran exclusiva competencia de los hombres. Pero, a pesar de las numerosas restricciones, comprobaremos que las mujeres tuvieron también protagonismo en los distintos ámbitos. 


\section{EL PROTAGONISMO DE LAS MUJERES EN EL IMPERIO ROMANO. DEL POLITEÍSMO TRADICIONAL AL MONOTEÍSMO CRISTIANO}

Palabras clave: Historia de las mujeres; Antigüedad tardía; cultos greco-romanos; cristianismo

ABSTRACT

In this chapter a tour is taken of the history of women in the Roman Empire, that is, in the first four centuries of our era. One of the unavoidable aspects to carry out this objective has to do with the prevailing religion at every moment, because in any society there has always been a set of religious beliefs, which has conditioned the existence of individuals. The information on the female condition comes mainly from the texts of men, from which their lives have been reconstructed. From them we know that women were officially excluded from politics and public life, and also relegated in the religious sphere, since the civilia officia were the exclusive competence of men. Despite the numerous restrictions, we will verify that women also played a leading role in the different fields.

Keywords: History of women; Late Antiquity; Greco-Roman cults; Christianity

\section{Introducción}

Desde mediados del siglo XX se ha publicado una ingente cantidad de estudios sobre la mujer en el Mundo antiguo, con orientaciones y enfoques dispares. Resultaría, por tanto, prácticamente imposible realizar un estado de la cuestión, debido al volumen de artículos y libros. El prejuicio registrado con más frecuencia en los diferentes estudios es el uso de parámetros actuales para analizar sociedades muy lejanas en el tiempo, como la de la Antigüedad, y, por tanto, muy diferentes a la nuestra. Pero debemos evitar caer en anacronismos, que nos impedirían llevar a cabo un estudio histórico serio. Hay que intentar situarse en el contexto preciso y, en la medida de lo posible, prescindir de nuestro sistema de valores.

Por otra parte, en la actualidad se constata la tendencia a incluir bajo la misma categoría trabajos científicos dispares, no todos clasificables como "estudios de género", y por ello me parece inadecuado asimilarlos. La perspectiva de género es un marco teórico adoptado en investigación, entre otros campos, con el objetivo de tener en cuenta los roles y desigualdades de género. Dicho enfoque implica el reconocimiento de que las relaciones de poder existentes entre los individuos generalmente favorecen a los varones como

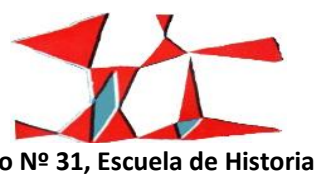


grupo social y resultan discriminatorias para las mujeres. Sin tener nada en contra de esa idea, y apoyando los estudios feministas, tan útiles para visibilizar la discriminación femenina en todas las épocas, creo que hay que distinguir algunos aspectos.

La historia sobre las mujeres es un campo de estudio necesario, que había sido dejado de lado hasta fechas recientes. La primera constatación que emerge de las fuentes es una situación de sometimiento y de inferioridad de las mujeres con respecto a sus parientes masculinos. Pero esta circunstancia no es exclusiva de una época o de una civilización, sino que ha sido una constante en todas las culturas y, por tanto, en todos los sistemas religiosos, perviviendo hasta el día de hoy. Así pues, no debemos obviar esa premisa a la hora de reconstruir los diferentes ámbitos de la vida de las mujeres y de poner de manifiesto su participación en el devenir de los hechos, pero tampoco podemos dejarnos llevar por un enfoque destinado exclusivamente a evidenciar la misoginia. Afortunadamente, hubo también muchos hombres que confiaron en las mujeres y las reconocieron como personas capaces de desempeñar tareas importantes en el ámbito público y privado.

En este capítulo voy a realizar un breve recorrido por la historia de las mujeres en el Imperio romano, es decir, el periodo que abarca los cuatro primeros siglos de nuestra era. Uno de los aspectos insoslayables para llevar a cabo ese objetivo tiene que ver con la religión predominante en cada momento, pues en cualquier sociedad ha existido siempre un conjunto de creencias y escrúpulos religiosos, que ha condicionado la existencia de los individuos, seguidores o no de un determinado credo. Dicha influencia se ha dejado sentir especialmente en la vida de las mujeres, pues cualquier religión se ha preocupado de regular el comportamiento sexual y matrimonial de sus fieles, dedicando particular atención al papel de la esposa. Desde antiguo, en todas las culturas mediterráneas se registra una división básica, basada en la separación natural de los sexos, según la cual al varón le corresponde el protagonismo en la vida pública y en la administración de la ciudad, mientras que a la mujer le incumbía el gobierno de la casa y la educación de los hijos. En definitiva, la división de los papeles entre uno y otro sexo se consideró como una derivación de las diferencias biológicas y automáticamente se convirtió en la inferioridad de las mujeres. 


\section{EL PROTAGONISMO DE LAS MUJERES EN EL IMPERIO ROMANO. DEL POLITEÍSMO TRADICIONAL AL MONOTEÍSMO CRISTIANO}

Como afirmaba Ulpiano, "feminae ab omnibus officiis civilibus, vel publicis remotae sunt" ${ }^{1}$. Excluidas de la política, sin derecho a tomar la palabra en público y relegadas en el ámbito religioso, las mujeres tampoco pudieron difundir sus escritos, que apenas conocemos. La información sobre la condición femenina procede fundamentalmente de los textos de los hombres, a partir de los cuales se ha reconstruido su vida. Por otra parte, debemos tener presente que no estamos informados sobre las mujeres de las diferentes clases sociales, sino sólo sobre las que pertenecían a la aristocracia. Respecto a las mujeres de las clases populares y de ambientes rurales apenas tenemos noticias. Para hacernos una idea global resultará útil trazar un breve recorrido por los aspectos fundamentales que constituían su día a día durante los primeros siglos del Imperio, estableciendo comparaciones con su situación en la etapa anterior, durante la República, para poner de manifiesto el relativo avance que la nueva época supuso para ellas en la consecución de libertades y derechos.

\section{La vida cotidiana}

\section{El matrimonio}

Antes del cristianismo son escasísimos los ejemplos de mujeres que permanecieron célibes, pues en la Antigüedad greco-romana su único destino era el matrimonio y la maternidad. Por influencia de la legislación romana, los 12 años era la edad legal para que las mujeres pudieran casarse y convertirse oficialmente en matronae, en esposas respetables. En otras civilizaciones, como la griega, tradicionalmente las mujeres contraían matrimonio con posterioridad, entre los 16 y los 18 años, hasta que las leyes romanas se hicieran extensibles a todo el Imperio. El acuerdo se establecía entre el padre de la joven y el futuro marido, de manera que no se precisaba ni se tenía en cuenta el consenso de ella. Durante la ceremonia del compromiso el novio regalaba a la novia un anillo. Puesto que normalmente el hombre aportaba al matrimonio una casa y un medio de subsistencia con su trabajo, la mujer contribuía con una dote en dinero o bienes como tierras, joyas o propiedades, pagada al marido por el padre de la novia. La comitiva del novio, familiares, amigos y clientes, llegaba a casa de la novia y allí se celebraba la ceremonia. La novia debía vestirse con una túnica especial, la tunica recta, con un cinturón de lana o cingulum herculeum de doble nudo y

\footnotetext{
1 Ulp., Digesto 50, 17, 2 pr.: Feminae ab omnibus officiis civilibus vel publicis remotae sunt et ideo nec iudices esse possunt nec magistratum gerere nec postulare nec pro alio intervenire nec procuratores existere.
}

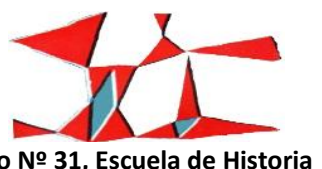

Anuario № 31, Escuela de Historia 
cubierta con un velo ritual de color azafrán llamado flammeum; además iba peinada a la manera tradicional romana, con seis trenzas y una diadema de hierro. Entonces, la joven unía su mano a la del novio, la dextrarum iunctio, en presencia de testigos que daban fe del hecho en el registro. Después se celebraba un sacrificio y finalmente un banquete con música y baile. Tras el banquete, al anochecer, todos acompañaban en procesión a los recién casados a su nueva casa.

El emperador Augusto, en su deseo de restablecer la moralidad y de fomentar el crecimiento demográfico, aprobó reformas legislativas que supusieron una revolución para el derecho familiar. Obligaba a los ciudadanos libres a casarse y a procrear, so pena de sanciones que implicaban la pérdida del derecho de sucesión. Prohibía que los hombres solteros entre 20 y 60 años y las mujeres entre 18 y 50 recibieran testamentos.

Al final de la República se había producido un paulatino resquebrajamiento de la patria potestas, que permitió a las mujeres nuevas libertades. En realidad la institución que experimentó una transformación más acusada fue el matrimonio, pues pasó de ser un contrato cum manu, que implicaba el traspaso de la mujer de manos del padre a las del marido o a la familia de éste, a ser sine manu, es decir, no se trataba ya de una compra de la esposa sino de una relación personal basada en el deseo de convertirse en marido y mujer. En el matrimonio cum manu se exigía a la esposa la entrega de una dote, que pasaba a ser propiedad del marido, y se continuó haciendo también en el matrimonio sine manu pues, aunque no era un requisito jurídico, constituía un signo de prestigio social y se utilizaba para diferenciar un matrimonio de un concubinato. A partir de Augusto se establecieron disposiciones para limitar el poder del esposo sobre los bienes de la dote, hasta llegar a reconocer a la mujer el derecho de controlarlos.

Por su condición de "eterna menor", la mujer debía estar sometida siempre a la tutela de un varón, el padre, algún pariente o el marido. Sólo la mujer que hubiera tenido al menos tres hijos (ius trium liberorum) podía liberarse de ella. Pero esa tutela perpetua había ido sufriendo modificaciones en los últimos tiempos de la República, que significaron para las mujeres vías de escape, maneras indirectas de eludir esa sumisión. Entre ellas se reconocía la posibilidad de cambiar de tutor, sustituyendo al legítimo por uno de confianza que sólo ejerciera nominalmente el control y que le concediera a ella una libertad total. Incluso se permitió a cualquier mujer, cuyo tutor le hubiera impedido determinadas acciones, presentar un recurso contra él. Muchos maridos estipulaban en sus testamentos la posibilidad de que su viuda cambiara de tutor si no le

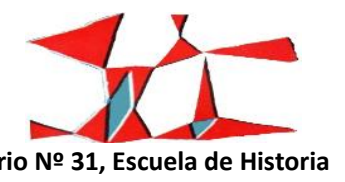




\section{EL PROTAGONISMO DE LAS MUJERES EN EL IMPERIO ROMANO. DEL POLITEÍSMO TRADICIONAL AL MONOTEÍSMO CRISTIANO}

satisfacía el que él le hubiera dejado asignado. La tutela cayó en desuso durante el Imperio, tal como lo justifican las reflexiones del jurista del s. II Gayo: "Si las mujeres adultas están bajo tutela es sin ninguna razón válida. Pues la que se alega comúnmente de que serían fáciles de engañar a causa de su frivolidad y que, por tanto, era justo tenerlas bajo la autoridad de sus tutores, es más una razón aparente que fundada”2.

Pero las mujeres no podían ejercer la tutela sobre sus propios hijos, ni siquiera como madres solteras, y tampoco podían adoptar. Sólo los favores imperiales explícitamente confirmados les permitían en algunos casos derogar esas estrictas prescripciones. Por tanto, durante los primeros siglos del Imperio y con no pocas dificultades, se fue aceptando que la tutela fuera también ejercida por las mujeres en determinadas circunstancias ${ }^{3}$.

Jurídicamente a las mujeres se les reconocía el derecho de tomar la iniciativa en la ruptura de un matrimonio, a diferencia de lo que ocurría en el judaísmo. Bastaba que uno de los dos manifestara la ausencia de afecto -affectio maritalis-, de voluntad de continuar conviviendo como marido y mujer, para que el divorcio fuera concedido de manera automática, pues el consentimiento debía tener un carácter permanente, no sólo inicial. Por supuesto me estoy refiriendo a un reconocimiento jurídico de igualdad de derechos entre hombres y mujeres solo teórico, que en la práctica no sería aplicado de igual forma, pues los valores tradicionales no consideraban equiparable el divorcio solicitado por el marido o por la esposa y, por tanto, la sociedad sería mucho más intransigente cuando la decisión partiera de la mujer ${ }^{4}$. En cualquier caso, se trató de un paso importante en el reconocimiento teórico de la igualdad de derechos entre hombres y mujeres, comparado con la inexistencia de leyes semejantes en siglos anteriores y en otras civilizaciones.

La fidelidad femenina constituyó siempre un aspecto fundamental de la organización familiar, y por ello Augusto confió al Estado su control, exigiendo también a la familia y vecinos la denuncia de los adulterios. En realidad la obligación de fidelidad conyugal afectaba en Roma solamente a la mujer, como sucedía en todas las civilizaciones del Imperio. En la época primitiva la represión del adulterio de la esposa se dejaba a

\footnotetext{
2 Gaius, Institutiones I, 190: Feminas vero perfectae aetatis in tutela esse fere nulla pretiosa ratio suasisse videtur: Nam quae vulgo creditur, quin levitate animi plerumque decipiuntur et aequum erat eas tutorum auctoritate regi, magis speciosa videtur quam vera. ${ }^{3} \mathrm{Cf}$. Treggiari, Susan; Roman marriage. lusti coniuges from the time of Cicero to the time of Ulpian; Oxford; 1993.

4 Sobre el tema del divorcio en las élites romanas cf. Raepsaet-Charlier, Marie-Thérèse; "Ordre sénatoriel et divorce sous le HautEmpire romain: un chapitre de l'histoire des mentalités", ACD 17-18; 1981-1982; pp. 161-173.
}

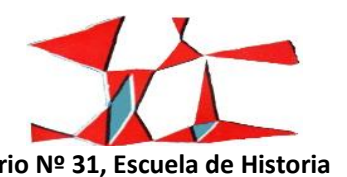


discreción del padre o del marido, que podía incluso matarla. La legislación de Augusto destinada a impedir el adulterio (lex Iulia de adulteriis coercendis) exigía al marido repudiar a su mujer y entablar diligencias penales, pues si la perdonaba era perseguido él como adúltero, exiliado y represaliado con parte de sus bienes. El castigo de la esposa consistía en la relegación a una isla -como el caso de las dos Julias, la hija y la nieta de Augusto- así como en penalizaciones de carácter patrimonial.

A partir del siglo I en la literatura encontramos referencias muy numerosas al aborto, al igual que a los métodos anticonceptivos, pero desconocemos el alcance real de tales prácticas. Aline Rousselle lo resumió con claridad:

"Tenemos la certeza de que la contracepción, el aborto, el infanticidio y la eliminación de las niñas eran efectivamente practicados, pero no sabemos en qué proporciones. Los antiguos se refieren a tales prácticas como normales hasta que los judíos y después de ellos los cristianos se las atribuyeran exclusivamente a los paganos, confiriéndoles un valor negativo y pecaminoso" ${ }^{15}$.

Probablemente estaría bastante difundida la práctica de interrumpir el embarazo, pese a la prohibición legal, como ha ocurrido en todas las épocas, pero lo más interesante para nosotros reside en conocer las causas de su prohibición. Para los romanos el aborto era reprobable en tanto en cuanto constituyera una decisión unilateral por parte de la esposa, pues significaba la usurpación de un derecho que le competía sólo al hombre. En nada influía la idea de que podía tratarse de la eliminación de una vida humana, como después lo consideraron los cristianos, pues para ellos el feto no era un hombre, sino solo la esperanza de un ser vivo ${ }^{6}$. Los hombres acusaban a las mujeres de recurrir a esa práctica sin solicitar el consentimiento de sus esposos por motivos vergonzantes, como esconder el resultado de relaciones adúlteras, o por causas fútiles como evitar la deformación de su cuerpo. Nuevamente constatamos el proceso de transformación que el derecho estaba experimentando durante la época imperial con respecto a la equiparación femenina, pero sólo se veía reflejado en las costumbres de algunas mujeres, las más cultas, ricas y decididas. La sociedad continuó mirando con desprecio y suspicacia a las mujeres emancipadas, cuyo comportamiento era equiparado a

\footnotetext{
${ }^{5}$ Rousselle, Aline; "La politica dei corpi: tra procreazione e continenza a Roma"; en Georges Duby-Michelle Perrot (eds.); Storia delle donne in Occidente. L'Antichità ; Roma-Bari; 1990; pp. 317-372, p. 335.

${ }^{6}$ Así lo afirmaba Papiniano en el Digesto 35,2, 9,1 (Pap. 19 quaest.): partus nondum editus nasciturus homo non recte dicitur; y Digesto, 11, 8, 2: (foetus) spes animantis.
}

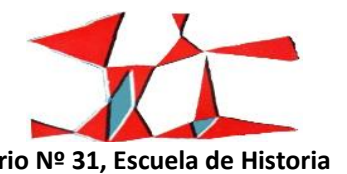




\section{EL PROTAGONISMO DE LAS MUJERES EN EL IMPERIO ROMANO. DEL POLITEÍSMO TRADICIONAL AL MONOTEÍSMO CRISTIANO}

actitudes de lujuria, promiscuidad y libertinaje. Pero al menos se había plantado la semilla de una progresiva libertad y emancipación de las mujeres ${ }^{7}$.

\section{La política}

Si desde finales de la República y durante el primer siglo del Imperio las mujeres habían ido consiguiendo numerosas conquistas, todavía les estaba vetada cualquier actividad política, reservada siempre a los hombres, tanto en Grecia como en Roma. Hubo múltiples aspectos derivados de la inferioridad de la mujer en el derecho romano que limitaron de manera importante su libertad de acción. La primera de esas limitaciones es la ausencia de derechos políticos, pues una mujer, aunque civis romana, no podía ejercer ninguna de las competencias esenciales del ciudadano romano, como servir al ejército, votar en las asambleas o hacerse elegir magistrado. Las restricciones en materia judicial son explicitadas por el jurista Ulpiano, como antes hemos señalado ${ }^{8}$. De la misma manera que una mujer estaba inhabilitada para ejercer una magistratura, tampoco podía demandar ante la justicia, ni desarrollar un proceso en beneficio de un tercero en calidad de procurator o administrador, porque ocuparse de los intereses de otro era un oficio civil, público y viril. No tenía capacidad para ser juez y tampoco para actuar como acusadora, salvo cuando se trataba de vengar a sus parientes más próximos. Podía testimoniar durante un proceso, pero no ser testigo de un testamento pues se trataba de validar una operación confiriéndole publicidad y ése era un deber masculino (virile officium), que atentaba contra la naturaleza y contra el pudor de la mujer.

Pero en ocasiones las limitaciones afectaban sólo al plano teórico, pues de facto fueron a menudo desatendidas. En la documentación epigráfica se registran testimonios de mujeres que asumieron cargos, liturgias y sacerdocios en sus ciudades y que realizaron grandes donaciones ${ }^{9}$. Gracias a la práctica de la evergesía, implantada en las ciudades del Imperio romano, las mujeres pudieron ostentar su poder y la preeminencia de su posición social, ya que les permitía acrecentar su prestigio personal y competir por la obtención de honores. Concretamente en Hispania, desde mediados del siglo I d.C. las mujeres

\footnotetext{
${ }^{7}$ Sobre todas esas cuestiones remito a la ya clásica obra de Cantarella, Eva; L'ambiguo malanno. Condizione e immagine della donna nell'antichità greca e romana; Roma; 198; pp. 185-207.

8 Ulp., Digesto 50, 17, 2.

${ }^{9}$ Cf. Van Bremen, Riet; The limits of participation. Women and civic life in the Greek East in the Hellenistic and Roman periods; Amsterdam; 1996.
}

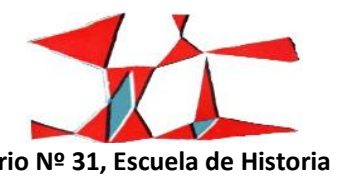


desempeñaron un importante papel en la práctica del evergetismo, en la recepción de honores públicos y en el desempeño de sacerdocios ${ }^{10}$.

También las fuentes literarias nos han transmitido información abundante sobre la participación de las mujeres de la aristocracia en el desarrollo político del Imperio romano. Generalmente se trataba de mujeres con gran influencia sobre los personajes masculinos. Eran las esposas, hijas, hermanas y parientes del emperador, que desempeñaron un papel fundamental en las decisiones del poder civil. Mención especial merecen los nombres de las esposas de los emperadores de la dinastía Julio-Claudia, cuyo poder e influencia política fueron notables, llegando a ascender al cargo de cónsules o senadores a los hombres que ellas decidían, o a hacerles caer en desgracia. Tal fue el caso de Livia, esposa de Augusto y madre de Tiberio, que fue llamada Iulia Augusta y hasta se le concedieron honores divinos. Mesalina desempeñó un papel fundamental en la política imperial, debido a sus intrigas y al carácter débil y pusilánime de su esposo Claudio. Agripina fue la siguiente esposa de Claudio, cuando Mesalina fue asesinada, y consiguió que el emperador adoptase a su hijo Nerón y que le sucediera en el trono a su muerte. El ansia de poder de esta mujer parecía insaciable hasta el punto que consiguió que Nerón delegara en ella todos los asuntos de Estado. Notable influencia política ejerció también otra mujer relacionada con Nerón, su segunda esposa Popea. En su afán de hacerse con el poder, esta ambiciosa mujer influyó en la caída en desgracia y muerte de Agripina, por acusarla de conspiración contra su hijo; también participó mediante embustes en la orden de suicidio que Nerón dio a Séneca; y algunos incluso sospechan que habría sugerido a su marido acusar a los cristianos del incendio de Roma en el año 64. Debido a la falta de reconocimiento legal para intervenir en política y en los virilia officia, esas emperatrices influyeron en el gobierno del Imperio del siglo I de manera determinante, pero mediante una participación indirecta, la manera más habitual, por otra parte, de ejercer su poder las mujeres.

\section{La sociedad y la cultura}

En el Mundo antiguo tradicionalmente las mujeres no recibían educación, como se pone de manifiesto en el gran porcentaje de analfabetismo femenino que existía. Pero ya desde la época helenística,

\footnotetext{
${ }^{10}$ Cf. Melchor Gil, Enrique; "Mujeres y evergetismo en la Hispania romana”; en Juan Francisco Rodríguez Neila (ed.), Hispania y la epigrafía romana, cuatro perspectivas. Epigrafia e Antichità 26; Faenza; 2009; pp. 133-178.
}

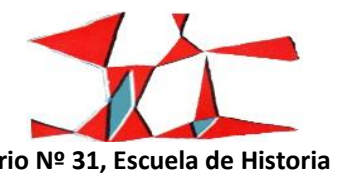




\section{EL PROTAGONISMO DE LAS MUJERES EN EL IMPERIO ROMANO. DEL POLITEÍSMO TRADICIONAL AL MONOTEÍSMO CRISTIANO}

y posteriormente durante el Imperio, la cultura entre las mujeres fue en aumento, pues aprovecharon la posibilidad de instruirse y cultivarse intelectualmente para participar en actividades hasta entonces típicamente masculinas ${ }^{11}$. La formación cultural femenina llegó a tal nivel que durante el siglo I las pinturas pompeyanas y los bajorrelieves de los sarcófagos representan a mujeres que leen, con un rótulo en la mano, o con el estilo y las tablillas para escribir. También la literatura recoge abundantes testimonios de mujeres de la aristocracia que adquirieron protagonismo en el cultivo de las letras. Plinio el Viejo y Tácito se refieren a las memorias redactadas por Agripina, la madre de Nerón, lamentablemente perdidas ${ }^{12}$. Marcial cita a la poetisa Sulpicia como ejemplo para las demás matronas, por sus relatos castos y honrados y sus bromas delicadas, en absoluto procaces ${ }^{13}$.

Séneca lamenta que su madre, Helvia, no pudiera entregarse al estudio de la filosofía, porque su padre se lo impidió, influido por las costumbres tradicionales, que lo veían con malos ojos, y por los desafortunados ejemplos de las mujeres que se sirvieron de las letras con fines lujuriosos y no para adquirir sabiduría:

“iOjalá mi padre, sin duda el mejor de los hombres, menos aferrado al uso de los antepasados, hubiera querido que te instruyeras en los preceptos de la sabiduría mejor que te iniciaras sólo! No

\footnotetext{
11 Sobre la educación de las mujeres en la Antigüedad cf. Haines-Eitzen, Kim; "Girls Trained in Beautiful Writing": Female Scribes in Roman Antiquity and Early Christianity"; Journal of Early Christian Studies 6, 4; 1998; pp. 629-646; Keener, Graig; "Women's Education And Public Speech In Antiquity"; Journal of the Evangelical Theological Society 50,4; 2007; pp. 747-759; Osiek, Carolyne; "The Education of Girls in Early Christian Ascetic Traditions"; Studies in Religion / Sciences Religieuses 41(3); 2012; pp. 401-407; Caldwell, Lauren; Roman Girlhood and the Fashioning of Femininity; Cambridge University Press; 2015; Hemelrijk, Emily A.; "The education of Women in Ancient Rome"; in W. Martin Bloomer (ed.); A Companion to Ancient Education, John Wiley \& Sons, Inc, Hoboken, NJ; 2015; pp. 292-304; y Martínez Maza, Clelia; "Cristianas sabias, arquetipo femenino en el mundo tardoantiguo. Una aproximación historiográfica"; Revista de historiografía (RevHisto), no 22; 2015; pp. 83-100.

12 Plin., Hist. Nat. 7, 8, 46: "También Nerón, príncipe hace poco tiempo y enemigo del género humano durante todo su principado, nació de pie, según escribe Agripina, su madre..." (Neronem quoque, paulo ante principem et toto principatu suo hostem generis humani, pedibus genitum scribit parens eius Agrippina) (tr. esp. Del Barrio Sanz, Encarnación; Garcia Arribas, Ignacio; Moure Casas, Ana María; Hernández Miguel, Luis Alfonso; y Arribas Hernáez, Ma Luisa; ed. Gredos; vol. III; Madrid; 2003; ed. Karl Friedrich Theodor Mayhoff); y Tac., Ann. 4, 53: "Esto no ha sido relatado por los historiadores, sino que lo he encontrado en las memorias de Agripina la joven, la madre del emperador Nerón, que ha transmitido a la posteridad su vida y los avatares de los suyos" (id ego, a scriptoribus annalium non traditum, repperi in commentariis Agrippinae filiae quae Neronis principis mater vitam suam et casus suorum posteris memoravit) (tr. esp. José Luis Moralejo; ed. Gredos, vol. I; Madrid; 1979; eds. Alfred John Church \& William Jackson Brodribb).

13 Mart. 10, 35: Omnes Sulpiciam legant puellae, Uni quae cupiunt viro placere; Omnes Sulpiciam legant mariti, Uni qui cupiunt placere nuptae. Non haec Colchidos adserit furorem Diri prandia nec refert Thyestae; Scyllam, Byblida nec fuisse credit: Sed castos docet et probos amores, Lusus, delicias facetiasque. Cuius carmina qui bene aestimarit, Nullam dixerit esse nequiorem, Nullam dixerit esse sanctiorem (tr. Fernández Valverde, Juan y Ramírez de Verguer, Antonio; ed. Gredos, vol. II; Madrid; 1997; ed. The Latin Library).
}

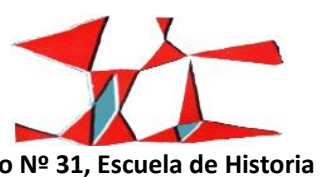

Facultad de Humanidades y Artes (Universidad Nacional de Rosario), 2019

ISSN 1853-8835 
tendrías ahora que procurarte defensas contra la suerte, sino sacar las tuyas. Por culpa de esas que no utilizan las letras por saber sino que se instruyen en ellas por ostentación, apenas consintió que te dedicaras a los estudios. Sin embargo, gracias a tu ávida inteligencia sacaste de ellos más de lo que permitía el tiempo: están echados los cimientos de todas las ciencias; regresa a ellas ahora; te prestarán protección"14.

Las referencias a mujeres que alardeaban de sus conocimientos hablando en griego, y también al fastidio de su compañía, abundan en las sátiras de Juvenal, especialmente en la VI, con un tono de evidente menosprecio:

"Pues, ¿qué cosa de peor gusto que el que una mujer no se considere guapa, sino aquélla que de etrusca se ha convertido en griega y, de natural de Sulmo, ateniense pura? Todo en griego, siendo así que es vergonzoso para las nuestras no saber latín; en aquella lengua expresan sus miedos, en ella la ira, los gozos, las cuitas. En ella desembuchan todos los secretos del alma ¿Qué más? Se acuestan en griego..."15.

Pero no debemos olvidar que la instrucción era un derecho exclusivo de las clases privilegiadas, y fundamentalmente de ámbito urbano, pues las mujeres humildes y de ambientes rurales no tenían esas posibilidades. Estos ejemplos indican que en los inicios del Imperio hubo muchas mujeres cultas y con inquietudes literarias, cuyos antecedentes se registran ya durante la República con algunos nombres propios como Cornelia, la madre de los Graco, que fue también su maestra, y su homónima, la esposa de Pompeyo, experta en tocar la lira e instruida en literatura y en geometría, o también Aurelia, la madre de César, y Azia, la madre de Augusto; todo parece indicar que en la época imperial se trató de un fenómeno más generalizado.

14 Sen., De cons. Ad Helv. 17, 4: Vtinam quidem uirorum optimus, pater meus, minus maiorum consuetudini deditus uoluisset te praeceptis sapientiae erudiri potius quam inbui! non parandum tibi nunc esset auxilium contra fortunam sed proferendum. Propter istas quae litteris non ad sapientiam utuntur sed ad luxuriam instruuntur minus te indulgere studiis passus est. Beneficio tamen rapacis ingenii plus quam pro tempore hausisti; iacta sunt disciplinarum omnium fundamenta: nunc ad illas reuertere; tutam te praestabunt. 5. Illae consolabuntur, illae delectabunt, illae si bona fide in animum tuum intrauerint, numquam amplius intrabit dolor, numquam sollicitudo, numquam adflictationis inritae superuacua uexatio ((tr. esp. Mariné Isidro, Juan; ed. Gredos; Madrid; 1996; ed. The Latin Library).

15 Juv. VI, 185-191: nam quid rancidius quam quod se non putat ulla formosam nisi quae de Tusca Graecula facta est, de Sulmonensi mera Cecropis? omnia Graece: (cum sit turpe magis nostris nescire Latine). hoc sermone pauent, hoc iram, gaudia, curas, hoc cuncta effundunt animi secreta. quid ultra? concumbunt Graece... (The Latin Library).

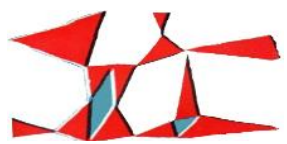

Anuario № 31, Escuela de Historia 


\section{EL PROTAGONISMO DE LAS MUJERES EN EL IMPERIO ROMANO. DEL POLITEÍSMO TRADICIONAL AL MONOTEÍSMO CRISTIANO}

La consideración del siglo I como la época de la emancipación femenina, con la consiguiente relajación de costumbres y la libertad sexual, está ya superada, pues no resulta históricamente válida en términos absolutos $^{16}$. Se trata de una utilización de conceptos actuales, referidos a épocas del pasado que eran completamente distintas. Es cierto que las mujeres habían ido adquiriendo nuevos derechos que contribuyeron a mejorar su situación, sobre todo debido a una mayor independencia del poder masculino, pero la sociedad de esa época, profundamente conservadora y patriarcal, apenas consentía actitudes de libertad femenina, consideradas inmorales y contrarias al mos maiorum.

Ahora bien, no se puede negar que el modelo ideal de la matrona romana, representado a la perfección por Turia en el siglo I a.C., cuyo epitafio resume ese cúmulo de virtudes ${ }^{17}$, continuaba vigente sólo a nivel teórico, ya que en la práctica iba cambiando. Así, en los textos literarios encontramos a muchas mujeres que asistían a los banquetes y se divertían en términos de igualdad con los hombres, conversando, bailando y bebiendo vino: "Quien crea que Acerra apesta a vino de ayer se equivoca; Acerra bebe siempre hasta el amanecer" (Marcial 1, 28); "Mírtale suele oler fuertemente a vino pero, para engañarnos, mastica hojas de laurel y, cauta, mezcla el vino con hojas, no con agua. A esta tú, cuantas veces la veas venir, roja y con las venas hinchadas, podrás decir: "Mirtale ha bebido laurel" (Marc. 5, 4); "La mujer que, ya promediada la noche, muerde grandes ostras, cuando los perfumes espumean diluidos en puro vino de Falerno, cuando se bebe en vasos de concha, cuando el techo ya le da vueltas del mareo y la mesa se levanta hasta ella con velas dobles" (Juvenal VI, 302-305); y "Por los mármoles se apresuran los hilillos, el velicomen de oro apesta a Falerno, porque igual que una serpiente larga cae en un tonel profundo, bebe y vomita" (Juv. VI, 430-432) ${ }^{18}$.

\footnotetext{
${ }^{16}$ Cf. Pau, Guy; L'émancipation fémenine dans la Rome Antique: París; Les Belles Lettres; 1978; Sirago, Vito Antonio; Femminismo a Roma nel primo Impero; Roma; 1983; y Mañas Núñez, Manuel; "Mujer y sociedad en la Roma imperial del siglo I"; Norba. Revista de Historia; vol. 16; 1996-203; pp. 191-207.

${ }^{17}$ La primera traducción al castellano de ese extenso epitafio fue realizada por Jose María Robles y apareció como obra póstuma en Robles, José Ma y Torres, Juana; “Epitafio de una esposa ejemplar: la Laudatio Turiae”; en Juana Torres (ed.); Historica et Philologica in honorem J. M. Robles; Universidad de Cantabria; 2002; pp. 15-27.

18 Marcial, 1, 28: Hesterno fetere mero qui credit Acerram, fallitur: in lucem semper Acerra bibit; Marcial 5, 4: Fetere multo Myrtale solet uino, sed fallat ut nos, folia deuorat lauri merumque cauta fronde, non aqua, miscet; Juvenal, VI, 302-305: grandia quae mediis iam noctibus ostrea mordet, cum perfusa mero spumant unguenta Falerno, cum bibitur concha, cum iam uertigine tectum, ambulat et geminis exsurgit mensa lucernis; Juv. VI, 430-432: marmoribus riui properant, aurata Falernum peluis olet; nam sic, tamquam alta in dolia longus deciderit serpens, bibit et uomit.
}

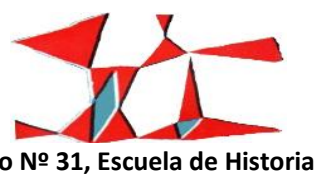

Anuario № 31, Escuela de Historia

Facultad de Humanidades y Artes (Universidad Nacional de Rosario), 2019 ISSN 1853-8835 
Otras frecuentaban los baños públicos: "De noche se encamina a los Baños, de noche ordena movilizar los frascos de ungüento y su logística; disfruta saludando en medio de un cisco de órdago"19; asistían a todos los espectáculos: "Ese mismo año los espectáculos de gladiadores tuvieron igual magnificencia que los anteriores, pero más mujeres ilustres y senadores fueron envilecidos por medio de la arena"; e, incluso, participaban en ellos, como es el caso de las carreras y de las luchas de gladiadores: "Organizó asiduamente magníficos y suntuosos espectáculos no sólo en el anfiteatro, sino también en el circo;... Y hubo luchas de hombres y también de mujeres..." ${ }^{20}$.

\section{La religión}

Tradicionalmente se ha considerado que en las distintas religiones oficiales las mujeres desempeñaron el papel de meras espectadoras, sin ninguna posibilidad de participación activa en los ritos de culto, ni de desempeñar puestos de responsabilidad. Es cierto que, tanto en la religión pagana como en la judía, las competencias sacerdotales públicas estuvieron casi siempre en manos de los hombres. Los flámines, los pontífices y los rabinos eran de sexo masculino y, con honrosas excepciones como el caso de las Vestales, en los templos y en las sinagogas la mujer estaba excluida de la escena ritual. Sólo en las religiones mistéricas parece que se le reconoció cierto protagonismo o, al menos, mayor grado de participación, de ahí el gran número de adeptas a los nuevos cultos cuando estos aparecieron.

A continuación voy a trazar un recorrido por las religiones del mundo greco-romano para conocer la situación de las mujeres en los diferentes cultos y analizar a continuación el papel reservado a ellas en el cristianismo, constatando la pervivencia de algunas actitudes y el cambio de otros comportamientos.

\section{La mujer en los cultos greco-romanos}

Frente a la consideración generalizada de que la autoridad religiosa en el mundo antiguo estuvo siempre en manos de los hombres, hay que reconocer que las mujeres también ocuparon un espacio importante en ese ámbito; tuvieron, sin embargo, un papel ambiguo. Estaban relegadas a una posición

\footnotetext{
19 Juvenal, VI, 419-420: grauis occursu, taeterrima uultu balnea nocte subit, conchas et castra moueri nocte iubet, magno gaudet sudare tumultu...

20 Tácito, Ann. 15, 32 spectacula gladiatorum idem annus habuit pari magnificentia ac priora; sed feminarum inlustrium senatorumque plures per arenam foedati sunt (tr. esp. Moralejo, José Luis; ed. Gredos, vol. I; Madrid; 1979; eds. Church, Alfred John \& Brodribb, William Jackson); Suetonio, Vit. Caes. 4, 1-4: Spectacula assidue magnifica et sumptuosa edidit non in amphitheatro modo, verum et in circo; nec virorum modo pugnas, sed et feminarum... in stadio vero cursu etiam virgines (Picón, Vicente; ed. Cátedra; Madrid; 1998).
}

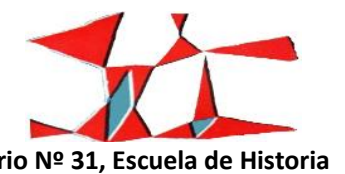




\section{EL PROTAGONISMO DE LAS MUJERES EN EL IMPERIO ROMANO. DEL POLITEÍSMO TRADICIONAL AL MONOTEÍSMO CRISTIANO}

marginal, pero no excluidas de los cultos religiosos. Como diversos estudiosos han señalado, se registra una situación paradójica, pues las mujeres estaban apartadas y subordinadas al poder masculino, pero al mismo tiempo eran necesarias e incluso complementarias en las tareas religiosas ${ }^{21}$. Ya Dionisio de Halicarnaso explicaba que, desde los orígenes de la ciudad, se cumplía lo siguiente: "Puesto que también algunos ritos debían ser realizados por mujeres y otros por niños... y para que también estos se llevasen a cabo de la mejor manera, se había establecido que las mujeres de los sacerdotes ayudasen a sus maridos en los actos religiosos, y si no era lícito que fuesen celebrados por hombres según la ley local, ellas los cumplirían y sus hijos asistirían a las ceremonias fijadas para ellos"22.

La bibliografía sobre mujeres y religión en la Antigüedad es inmensa y, por ello, intentaré sintetizar la información al respecto, con el objetivo de constatar esa doble vertiente de marginación oficial por un lado, y de participación real por otro ${ }^{23}$. Las mujeres desempeñaron de manera incuestionable puestos en un amplio espectro de las religiones paganas a lo largo del Mundo antiguo. Muchos festivales romanos de carácter oficial incorporaban la participación de las matronas, como las Matronalia, dedicadas a Juno Lucina y relacionadas

\footnotetext{
${ }^{21}$ Esa paradoja ha sido señalada por diversos autores: John Scheid habla de "Extranjeras, extrañas indispensables" (“Indispensabili "straniere». I ruoli religiosi delle donne a Roma"; en Georges Duby y Michel Perrot; Storia delle donne; P. Schmitt Pantel (ed.); L'Antichità; Roma; 1990; pp. 424-462); Sarah B. Pomeroy titula su libro Diosas, rameras, esposas y esclavas (Goddesses, Whores, Wives, and Slaves: Women in Classical Antiquity; Nueva York; 1975); Pilar Pavón sitúa a la mujer "entre la participación y la marginación" ("La mujer en la religión romana: entre la participación y la marginación”; en Eduardo Ferrer Alveda, y Álvaro Pereira Delgado, (eds.); Hijas de Eva. Mujeres y religión en la Antigüedad; Sevilla; 2015; pp. 115-141); y Marie Thérèse Raepsaet-Charlier las denomina "indispensables pero incapaces" ("Indispensables pero incapaces: las mujeres romanas en el Derecho y la Religión"; Annaeus 3; 2006; pp. 161-181); también afirma que "...las mujeres desempeñan en la religión romana papeles indispensables"; y que "No se debe hablar de marginalidad religiosa de las mujeres, hay que señalar más bien su complementariedad..." ("La place des femmes dans la religión romaine: marginalization ou complementarieté? L'apport de la théologie”, en Pavón, Pilar (ed.); Marginación y mujer en el Imperio romano; Edizioni Quasar; Roma; 2018; pp. 201-219, p. 218).

22 Dion. Halic., Antiquitates romanae II, 22,1-2 (tr. esp. Jiménez, Elvira y Sánchez, Ester; Historia antigua de Roma; vol. 1; ed. Gredos; 1984).

${ }^{23}$ Por mencionar solo algunos de los títulos más importantes, cf. Cantarella, Eva; L'ambiguo malanno. Condizione e immagine della donna nell'antichità greca e romana; Roma; 1981; Scheid, John; "Indispensabili "straniere». I ruoli religiosi delle donne a Roma", en Georges Duby y Michel Perrot; Storia delle donne; P. Schmitt Pantel (ed.); L'Antichità; Roma; 1990; pp. 424-462; Sfameni Gasparro, Giulia; "Ruolo cultuale della donna in Grecia e a Roma: per una tipologia storico-religiosa"; en Ugo Mattioli (ed.); Donna e culture. Studi e documenti nel III anniversario della "Mulieris dignitatem"; Génova; 1991; pp. 57-121; Kraemer, Ross Shepard; Her Share of the Blessings. Women's Religions among Pagans, Jews and Christians in the Graeco-Roman World; Nueva York-Oxford; 1992; Scheid, John; "Les rôles religieux des femmes à Rome. Un complément", en Regula Frei-Stolba, Anne Bielman y Olivier Blanchi (eds.); Les femmes antiques entre sphere privée et sphere publique; Berna; 2003; pp. 137-151; Kraemer, Ross Shepard (ed.); Women's Religions in the Greco-Roman World. A Sourcebook; Oxford University Press; 2004; Takács, Sarolta A.; Vestal Virgins, Sibyls and Matrons. Women in Roman Religion; Universidad de Texas; 2008; Pavón, Pilar, "La mujer en la religión romana: entre la participación y la marginación", en Eduardo Ferrer Alveda, y Álvaro Pereira Delgado (eds.); Hijas de Eva. Mujeres y religión en la Antigüedad; Sevilla; 2015; pp. 115141; Pavón, Pilar (ed.), Marginación y mujer en el Imperio romano; Edizioni Quasar; Roma; 2018,
}

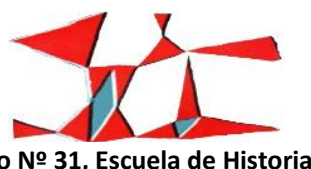

Anuario № 31, Escuela de Historia

Facultad de Humanidades y Artes (Universidad Nacional de Rosario), 2019 ISSN 1853-8835 
con el parto; las Veneralia, ofrecidas a Venus por las mujeres de la élite, aunque también la veneraban las de las clases inferiores; las Vestalia, en las que las matronas llevaban ofrendas de mola o harina ritual al templo de Vesta; las Matralia, celebradas en el templo de Mater Matuta; las Carmentalia, en honor de Carmenta, la diosa que evitaba los partos de nalgas; así como los ritos secretos a Bona Dea, celebrados en casa de un magistrado cum imperio, y en los que sacrificaban a una cerda preñada y hacían libaciones de leche y miel, además de beber vino puro. Había también otras divinidades femeninas a las que las mujeres rendían culto, como Fortuna Virginalis, Fortuna Primigenia, Pudicitia, Venus Verticordia, Venus Obsequens, etc. Aunque la mayoría de los sacerdotes de los cultos oficiales romanos fueron hombres, uno de los más famosos en Roma fue desempeñado por mujeres, es decir, el de las Vírgenes Vestales ${ }^{24}$. Consagradas desde la infancia al servicio de Vesta, la diosa del hogar, cuidaban el fuego del templo, que simbolizaba al pueblo romano, y disfrutaban de considerables privilegios, como la emancipación de la tutela masculina y la posibilidad de hacer testamento. Estaban sometidas al castigo por el Pontifex Maximus, la cabeza del colegio de los sacerdotes del estado, y su mayor delito consistía en romper el voto de castidad durante el periodo de su cargo -30 años-. En ese caso eran encerradas vivas hasta su muerte.

Junto con las Vestales, las esposas de los flamines y del rex sacrorum eran sacerdotisas públicas y constituían, por tanto, una excepción en el sacerdocio romano. La flaminica y la regina sacrorum desempeñaban un papel complementario en las funciones sacerdotales de sus maridos y solo ellas tenían capacidad de ofrecer sacrificios, debido a su condición de esposas de hombres con autoridad religiosa. También las Vestales, con una situación jurídica excepcional, podían realizar sacrificios.

Si en la religión pública el poder pertenecía casi exclusivamente a los hombres, en el ámbito doméstico era igualmente el paterfamilias el responsable de los cultos familiares. La participación de las

\footnotetext{
24 De entre la numerosa bibliografía sobre este sacerdocio femenino, cf. Raepsaet-Charlier, Marie Thérèse; “L'origine sociale des Vestales"; en Panayotis D. Dimakis (ed.); Mnémè G. A. Petropoulos II; Atenas; 1984; pp. 253-270; Beard, Mary; "Re-Reading Vestal Virginity", en Richard Hawley \& Barbara Levick (eds.); Women in Antiquity: New Assessments; Routledge; Londres; 1995; pp. 166-177; Staples, Ariadne; From Good Goddes to Vestal Virgins: Sex and Category in Roman Religion; Routledge; Londres; 1998; Wildfang, Robin Lorsch; "The Vestal Virgins'Ritual Function in Roman Religion"; CM 50; 1999; pp. 227-234; Idem; "The Vestals and annual public rites"; Clas. et Med. 52; 2001; pp. 223-256; Parker, Holt; Why Were the Vestals Virgins? Or the Chastity of Women and the Safety of the Roman State; AJPh 125; 2004; pp. 563-601; Mekacher, Nina; Die vestalischen Jungfrauen in der römischen Kaiserzeit; Wiesbaden; 2006; y Takács, Sarolta A.; Vestal Virgins, Sibyls and Matrons. Women in Roman Religion; Universidad de Texas; 2008. Algunos estudiosos han comparado la institución de las vestales con la de las vírgenes cristianas, como se puede ver en: Lizzi, Rita; "Vergini di Dio - vergini di Vesta. II sesso negato e la sacralità"; en Salvatore Pricoco; L'Eros difficile. Amore e sessualità nell'antico cristianesimo, Soveria Manelli, Rubbettino; 1998; pp. 89-132; y Bybee, Ariel E.; "From Vestal Virgin to Bride of Christ: Elements of a Roman Cult in Early Christian Asceticism"; Studia Antiqua 1,1; 2001.
}

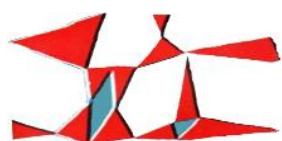

Anuario № 31, Escuela de Historia

Facultad de Humanidades y Artes (Universidad Nacional de Rosario), 2019 ISSN 1853-8835 


\section{EL PROTAGONISMO DE LAS MUJERES EN EL IMPERIO ROMANO. DEL POLITEÍSMO TRADICIONAL AL MONOTEÍSMO CRISTIANO}

mujeres nunca tuvo reservado un lugar importante. Los grandes rituales privados estaban en manos de los hombres, como las festividades de los muertos, los funerales y la celebración de los correspondientes sacrificios.

En la tradición clásica griega sabemos de la existencia de sacerdotisas al servicio de diosas griegas como Demeter, Hera, Atenea, Artemis y muchas otras, por las inscripciones y los textos literarios antiguos. Las sacerdotisas asistían a una divinidad en su santuario y eran responsables de su cuidado y de la estatua de la diosa; cumplían además los ritos de purificación y guardaban los tesoros y regalos del santuario. Tal vez el desempeño femenino del culto religioso se considerara como una extensión de sus responsabilidades domésticas. Especialmente conocida fue la actividad sacerdotal de las mujeres en la festividad de las Bacanales, en honor de Dioniso-Baco. En la antigua Grecia eran reuniones clandestinas de marcado sentido religioso, organizadas por las Bacantes. La participación en las mismas estaba reservada a mujeres y en ellas se llevaban a cabo diversos ritos religiosos en honor al dios Pan. Roma adoptó este culto, dotándolo de un carácter más festivo, para honrar al dios del vino Baco.

En los cultos orientales las divinidades estaban más cercanas a la sensibilidad popular y, por ello, más dispuestas a escuchar y a ayudar a sus fieles, prometiéndoles la felicidad en otra vida. Las religiones mistéricas conocieron una rápida difusión por todo el Imperio y llegaron a todas las clases sociales, de ahí que gran número de mujeres participaran en sus cultos y, de manera especial, en el de Isis, diosa egipcia que había contribuido en gran medida a dignificar la condición femenina. Proporcionaba consuelo a los humanos en sus sufrimientos y les inculcaba la esperanza en una vida después de la muerte. Podían ejercer el sacerdocio tanto hombres como mujeres, pues para esa diosa no existían diferencias de sexo ni de condición social. Con razón o de manera infundada, corrían rumores de que en el templo de Isis sus fieles cometían adulterio e, incluso, que las mujeres se prostituían, y esto impulsó a las autoridades a detener ese culto. Entre otros, parece que Augusto ordenó la demolición del templo de Isis y Cibeles en Roma, sin éxito, hasta que Tiberio lo consiguió en el año 19 d.C. Lo único cierto es que las religiones mistéricas introdujeron cambios sustanciales en la sociedad, los cuales suscitaban sospechas y preocupación entre los hombres. En palabras de la estudiosa Eva Cantarella:

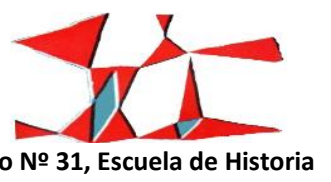

Anuario № 31, Escuela de Historia 
La difusión de los nuevos cultos perturbaba el orden establecido, arrojaba el desorden en el interior de las casas romanas y era visto como causa de una licenciosidad inadmisible [...] En nombre de los nuevos cultos estaban cambiando demasiadas cosas, demasiados principios eran sacudidos, demasiadas libertades eran reivindicadas por personas que antes nunca se habrían planteado poner en discusión su inferioridad. Esclavos y mujeres se consideraban ahora personas iguales a las demás [...]25.

Podemos concluir, por tanto, que la participación femenina en los cultos religiosos greco-romanos es indiscutible, aunque apenas existiera un reconocimiento oficial. La condición ideal de la mujer era la virginidad o el matrimonio, y en torno a esos estados se estructuraba su espacio religioso y su función en Roma. Por ello la participación femenina en el culto religioso estaba destinada a las matronas y a las muchachas vírgenes. Esta situación ha sido una constante a lo largo de la historia del Mundo antiguo, con independencia de las religiones. Resulta muy evidente en los primeros siglos del cristianismo, como veremos a continuación, y a grandes líneas sería extrapolable al mundo actual.

\section{La mujer en el cristianismo}

Antes he señalado que los nuevos cultos orientales, y especialmente el de Isis, contribuyeron sensiblemente a cambiar y mejorar la situación de las mujeres. Pero estos eran cultos de carácter privado, no oficial. Igualmente, otro culto difundió ideas nuevas y subversivas: el cristianismo.

\subsection{El Nuevo Testamento y los primeros autores cristianos}

La predicación de Jesús trajo consigo innovaciones radicales con respecto a la relación entre los sexos y cuestionó las concepciones judías y romanas. Por ejemplo, para Él el matrimonio debía ser monógamo e indisoluble. A los fariseos -secta mayoritaria entre los judíos- que, para provocarle, le habían preguntado si estaba permitido el repudio, les había respondido explicando que el hombre, en el momento del matrimonio, dejaba a su padre y a su madre para ser con su mujer "una sola carne", y que nadie debía, ni podía separar lo que Dios había unido (Mat. XIX, 3-9; Marc. X, 2-9). Otro principio predicado por Jesús y sus seguidores sacudía

\footnotetext{
25 Cantarella, Eva; L'ambiguo malanno. Condizione e immagine della donna nell'antichità greca e romana; Roma; 1981; p. 209: “II diffondersi dei nuovi culti, insomma, turbava l'ordine costituito, gettava lo scompiglio nelle case dei romani, era visto come causa di una inammissibile licenziosità [...] In nome dei nuovi culti troppe cose stavano cambiando, troppi principi venivano scossi, troppe libertà venivano rivendicate da persone che, prima, non avrebbero mai pensato di mettere in discussione la loro inferiorità: schiavi e donne, ora, si ritenevano "persone" uguali a tutte le altre" [...]
}

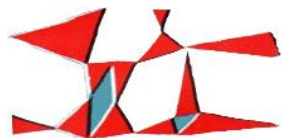

Anuario № 31, Escuela de Historia

Facultad de Humanidades y Artes (Universidad Nacional de Rosario), 2019

ISSN 1853-8835 


\section{EL PROTAGONISMO DE LAS MUJERES EN EL IMPERIO ROMANO. DEL POLITEÍSMO TRADICIONAL AL MONOTEÍSMO CRISTIANO}

una convicción secular de los romanos y judíos: Hombre y mujer tenían igual dignidad en el matrimonio. Pablo escribía: "El hombre debe cumplir su deber conyugal con su esposa, e igualmente la mujer con su esposo. La mujer no es dueña de su cuerpo, sino el marido; y así también, el marido no es dueño de su cuerpo, sino la mujer (I Cor., 7, 3-5).

Por consiguiente, en los textos evangélicos y en las cartas de Pablo se registra una ruptura con respecto a la consideración de la mujer en épocas y culturas anteriores. Las relaciones de Jesús con las mujeres, en comparación con el rigor del judaísmo de su tiempo, son de una libertad excepcional, como podemos ver en algunos ejemplos: Es recibido por Marta y María en su casa (Luc. 10, 38-42) y como agradecimiento resucitó a su hermano Lázaro (Juan 11). Cuando sus discípulos lo encuentran hablando con una Samaritana, junto al pozo de Jacob, se sorprenden de verlo hablar con una mujer extranjera (Juan 4, 27), y también ante la curación de la hija de una Cananea (Mat. 15, 21-28; Marc. 7, 24-30). Con su actitud se produce una subversión de la jerarquía tradicional, que supone ventajas para los grupos más despreciados, como las prostitutas (Mat. 21, 31), las mujeres pecadoras (Luc. 7, 36-49; Mat. 26, 6-13), concubinas (Juan 4, 17-18) y adúlteras, a las que Jesús perdona (Juan 8,1-11). Tampoco rechaza la impureza de las mujeres, como se observa en el relato de la que tiene una hemorragia y, tocando el manto de Jesús, consigue la curación (Mat. 9, 20-22). Es compasivo también con las mujeres más pobres y con las viudas, pues resucita al hijo único de la viuda de Naim (Luc. 7, 11-15), y alaba más a la pobre viuda que ofreció unas monedas, que a los ricos que depositan sus ofrendas en el Templo (Luc. 21, 1-3; Marc. 12, 41-44).

Algunos nombres de mujeres son mencionados entre los seguidores de Jesús, además de los doce apóstoles, como María Magdalena, Juana, mujer de Cusa, el intendente de Herodes, Susana y otras muchas que lo asistían con sus bienes (Luc. 8, 1-3). Este grupo de mujeres, que siguieron a Jesús transgrediendo las costumbres de sus contemporáneas (Marc. 15, 40-41; Mat. 27, 55-56), no fueron incluidas entre los doce, ni enviadas en misión. Pero demostraron una gran fidelidad ante la muerte de Jesús, frente al abandono de sus discípulos, pues permanecieron cerca de la Cruz, (Juan 19, 25-27), asistieron al entierro y prepararon especias aromáticas para ungir el cadáver. En conclusión, como testigos de la resurrección de Jesús, fueron encargadas de anunciarla a los discípulos (Marc. 16, 1; Luc. 23, 56; 24, 1).

En los Hechos de los Apóstoles se recogen testimonios de las primeras "casas-iglesia", prestadas por

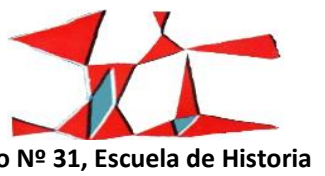

Anuario № 31, Escuela de Historia

Facultad de Humanidades y Artes (Universidad Nacional de Rosario), 2019

ISSN 1853-8835 
algunas propietarias para celebrar la asamblea de los fieles, y que otorgaron a las mujeres una función esencial (Hech. 12, 12-16). También tuvieron una parte importante en la asistencia y colaboración con Pablo a lo largo de sus viajes, como es el caso de Lidia, mercader de púrpura (Hech. 16, 13-15), o el de Prisca, esposa de Aquila, a quien saluda expresamente al final de su epístola a los Romanos: "Saludad a Prisca y Aquila, mis colaboradores en Cristo Jesús; para salvar mi cabeza han arriesgado la suya" (Rom. 16, 3-5). La larga lista de recomendaciones y de saludos que cierra esa carta contiene 10 mujeres, sobre un total de 30 personas. La primera a la que Pablo recomienda es "Febe, nuestra hermana que está al servicio (diàkonos) de la Iglesia de Cencres -puerto de Corinto-" (Rom. 16, 1-2). No sabemos con exactitud a qué se refiere su "servicio", pero no parece adecuado suponer que aludiera a las funciones de las futuras diaconisas, institucionalizadas en el siglo IV ${ }^{26}$. Otras cinco mujeres son también mencionadas entre las personas saludadas por Pablo: María, Trifena, Trifosa, Persides y Olimpia como "aquellas que han penado mucho" por los cristianos de Roma a causa del Señor (Rom. 16, 12 y 15), además de aludir a los lazos familiares: "Rufo y su madre", "María y su hermana", "Andrónico y Junia, "Filologo y Julia". No debemos olvidar que el propio Pablo pregunta en otra de sus epístolas: “¿No soy libre, no soy apóstol?..., ¿ No tenemos derecho de traer con nosotros una hermana por mujer como también los otros apóstoles, y los hermanos del Señor, y Cefas?" (I Cor. 9, 5). Lo que resulta difícil de interpretar es a qué se refiere el apóstol con ese tipo de relación, pero en todo caso revela la necesidad de hacerse acompañar por mujeres. Por tanto, en el Nuevo Testamento no se observa que las mujeres tuvieran asignado un estatuto subalterno, permaneciendo relegadas al ámbito femenino del hogar, sino más bien una equiparación.

Pero en la Iglesia en curso de institucionalización las mujeres no ocuparon oficialmente "ministerios" determinados. Con el paso del tiempo, comenzaron a formarse grupos particulares como el de las viudas, a las que se exigía una trayectoria irreprochable -un solo marido (univirae), cualidades maternales- y una vida de continencia y oración, haciendo obras de caridad-; y también el de las diaconisas, que son mencionadas por Pablo en el párrafo referido a los diàkonoi: "del mismo modo que ellos, las mujeres sean dignas, nada maledicentes, sobrias y fieles en todo" (I Timot. 3, 11), como si existiera una categoría paralela a la de los hombres diáconos, con cualidades y funciones análogas. Pero todo parece indicar que se aludía únicamente

${ }^{26}$ Cf. Gryson, Roger; Le ministère des femmes dans l'Église ancienne; Gembloux; 1972; pp.22-23; Martimort, Aimé Georges; Les diaconesses: Essai historique; Roma; 1982; pp. 15-16; y Aubert, Marie- Josèphe; Des femmes diacres. Un nouveau chemin pour l'Èglise; París; 1987; p. 69 y pp. 75-77.

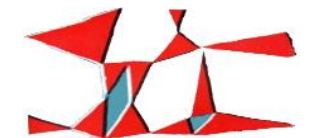




\section{EL PROTAGONISMO DE LAS MUJERES EN EL IMPERIO ROMANO. DEL POLITEÍSMO TRADICIONAL AL MONOTEÍSMO CRISTIANO}

a las esposas de los diáconos.

Por otra parte, el papel carismático de las mujeres era bastante marcado en los inicios del cristianismo. María, Elisabeth y Ana son mencionadas al comienzo del evangelio de Lucas, de forma paralela a las profetisas del Antiguo Testamento. Pablo recuerda su etapa en Cesarea, en casa de Felipe el evangelista, que tenía "cuatro hijas vírgenes que profetizaban" (Hechos 21, 9); en la asamblea litúrgica de Corinto, hombres y mujeres rezaban y profetizaban del mismo modo (I Cor. 11, 2-16). En el Apocalipsis se denuncia a una falsa profetisa, "Jezabel, esa mujer que se hace pasar por profetisa y enseña" (Apoc. 2, 20-24). Parece que este don perduró largo tiempo, pues Justino, en el s. II, hablaba de "hombres y mujeres cristianas que tienen carisma de parte del Espíritu Santo". En el 203, en Cartago, Perpetua describe en su “Diario de martirio" las diversas visiones que experimentó. Pero el carácter difícilmente controlable de estos dones y su despliegue en las sectas heréticas, en particular entre los Montanistas en el s. II, supuso la rápida cancelación de este papel por parte de la institución eclesiástica, sobre todo para las mujeres ${ }^{27}$. En los siglos sucesivos, la tendencia a la emancipación femenina sufrió no sólo una interrupción, sino más bien una involución ${ }^{28}$.

Hemos podido constatar que en tiempos de Jesús y de Pablo las mujeres dispusieron de cierta libertad para participar activamente en las primeras comunidades cristianas, pero, apenas comenzó a institucionalizarse la jerarquía de la iglesia, tomando como modelo las instituciones civiles, las mujeres fueron desautorizadas para tomar parte en cualquier oficio eclesiástico que implicara poder o superioridad sobre el hombre. Sus cometidos no debían trascender el plano asistencial, y siempre en calidad de ayudantes de la autoridad masculina.

\footnotetext{
${ }^{27}$ Cf. Ash, James L.; "The Decline of Ecstatic Prophecy in the Early Church"; Theological Studies 37; 1976; 227-252; y Marcos, Mar; "Mujer y profecía en el cristianismo antiguo", en Ramón Teja (ed.); Profecía, magia y adivinación en las religiones antiguas; Aguilar de Campóo; 2001; pp.103-104.

${ }^{28}$ Acerca de la participación de las mujeres en las primeras comunidades cristianas, cf. Schüssler y Fiorenza, Elizabeth; "Word, Spirit and Power: Women in Early Christian Communities"; en Rosemary Ruether y Eleanor McLaughlin (eds.); Women of Spirit. Female Leadership in the Jewish and Christian traditions; Nueva York; 1979; pp. 29-70; Guiducci, Armanda; Perdute nella storia. Storia delle donne dal I al VII secolo d.C.; Florencia; 1989; Mazzuco, Clementina; "E fui fatta maschio". La donna nel cristianesimo primitive; Turín; 1989; Kramer, Ross Shepard \& D'Angelo, Mary Rose; Women and the Origins of Christianity; Londres; 1999; Alexander, Monique; "Immagini di donne ai primi tempi della cristianità", en Georges Duby-Michelle Perrot (eds.); Storia delle donne in Occidente. L'Antichità ; Roma-Bari; 1990; pp. 465-513; esp. pp. 472-478; Torjesen, Karen J.; When Women Were Priest. Women's Leadership in the Early Church and the Scandal of Their Subordination in the Rise of Christianity; San Francisco; 1995.
}

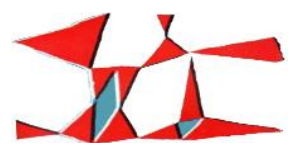

Anuario № 31, Escuela de Historia 
Durante el siglo II y parte del III las mujeres debían gozar de cierta relevancia en las comunidades religiosas, de modo bastante similar a la época de los apóstoles, tal como lo demuestran las fuentes contemporáneas. Así, Ignacio de Antioquía hacia el 110 saluda en sus cartas a varias mujeres como Tabia y Alce, que destacaban por la solidez de su fe y a las que apreciaba mucho (Policarpo de Esmirna, ep. 8, 2; ep. 13, 2); en la obra "El Pastor", escrita por Hermas hacia el 140, es mencionada Grapte, mujer de gran ascendencia en su comunidad a juzgar por el hecho de que le fue enviada una copia de ese libro para que instruyera a las viudas y huérfanos (Hermas, El Pastor, Visión II, 8, 3). Es decir, gozaba de un prestigio suficiente como para catequizar a otras personas. Al igual que en épocas anteriores, las mujeres ricas e influyentes contribuyeron con sus bienes y su apoyo a la defensa y difusión del cristianismo y de sus seguidores, como fue el caso de Marcia, la concubina de Cómodo (s. II) (Dión Casio, Historia romana, 72, 4, 7; e Hipólito de Roma, Refutación de todas las herejías, IX, 12, 10-12). En la correspondencia de Cipriano de Cartago (s. III), aparecen varios nombres de mujeres, como Numeria y Cándida, y también alusiones genéricas a los "hermanos y hermanas" que prestaron ayuda a otros cristianos (Cipriano, ep. 21, 2, 2 y 4, 1-2; ep. 22, 3, 2; ep. 62, 5, 2). Orígenes, escritor del siglo III, debió relacionarse con un número importante de mujeres, tanto en calidad de alumnas de su escuela como de benefactoras, que le asistieron cuando lo necesitaba, e incluso con algunos miembros de la casa imperial. Juliana de Cesarea, mujer "bastante culta y devota", le hospedó en su casa durante dos años en que tuvo que alejarse de Alejandría, y le ayudó en sus estudios bíblicos (Eusebio de Cesarea, $H E, \mathrm{VI}, 2,13-14)$. Para desarrollar su actividad como escritor, sabemos que Orígenes contaba con la ayuda de copistas y estenógrafos así como de "muchachas expertas en caligrafía" (Eusebio de Cesarea, $H E, \mathrm{VI}, 23,2)$; estando en Antioquía entre el 231-233 impartió lecciones de teología a la emperatriz Julia Mamea, la madre de Alejandro Severo (Eusebio de Cesarea, HE, VI, 21, 4) ; y mantuvo correspondencia con la esposa de Filipo el Árabe, Marcia Otacilia Severa (Eusebio de Cesarea, $H E$, VI, 36, 3).

En los siglos posteriores también se registra un importante número de mujeres que cumplieron un papel activo en la vida de la Iglesia, aunque generalmente de manera no oficial. Solo tres grupos femeninos "privilegiados" dispusieron del reconocimiento oficial para intervenir en algunas funciones litúrgicas. Se trata

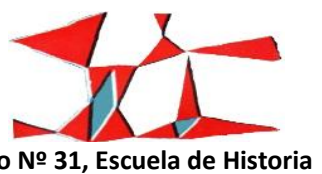




\section{EL PROTAGONISMO DE LAS MUJERES EN EL IMPERIO ROMANO. DEL POLITEÍSMO TRADICIONAL AL MONOTEÍSMO CRISTIANO}

de las viudas canónicas, de las vírgenes y de las diaconisas, las únicas instituciones femeninas existentes, pero que tenían asignadas unas tareas muy $\operatorname{precisas}^{29}$.

\subsection{Las persecuciones}

Las diversas fuentes literarias que hacen referencia a las persecuciones y al número de mártires afirman que hubo hombres, mujeres y niños, sin distinción de sexo, edad o condición. En efecto, las mujeres no sólo corrieron la misma suerte que sus compañeros, sino que compartieron idénticos sufrimientos y torturas, cumpliendo por igual las fases del proceso. Resulta llamativo que en la mayoría de los episodios sobre martirio aparezcan nombres de mujeres junto al de los hombres, y podemos constatarlo fácilmente echando una ojeada a los documentos. A partir del siglo I conocemos la existencia, a medio camino entre la realidad y la ficción, de Tecla, seguidora fiel de Pablo cuyos avatares son relatados en las "Actas de Pablo y Tecla"; su lealtad al apóstol le supuso pasar por dos martirios, en el fuego y con las fieras, resultando ilesa. A finales de siglo, hacia el año 95, fue desterrada a la isla de Poncia por su condición de cristiana una mujer noble, Flavia Domitila, bajo el emperador Domiciano. Dos madres, con sus correspondientes siete hijos, Sinforosa y Felicidad, murieron en el martirio bajo Adriano y Marco Aurelio respectivamente. Entre los compañeros de martirio de Justino, en el 166-67, se menciona a una mujer, Carito, que responde a la pregunta del prefecto en el mismo sentido que el resto de los hombres: "Soy cristiana por la gracia de Dios". El relato del martirio de Carpo, de fecha imprecisa, refiere la disponibilidad, valentía y entereza de Agatónice, que no renuncia a su fe ni siquiera ante el recuerdo de su hijo. Las "Actas de los Mártires de Lión" describen los hechos que tuvieron lugar entre el 177 y 178, bajo Marco Aurelio, y mencionan entre sus protagonistas a Blandina y a Bíblide. Fueron víctimas del martirio en África, en el año 180, doce cristianos, conocidos como los "mártires escilitanos" por el nombre de su ciudad (Scilium). Cinco de ellos eran mujeres: Jenara, Generosa, Vestia, Donata y Segunda.

\footnotetext{
${ }^{29}$ Sobre los ministerios femeninos, entre otros títulos cf. Danielou, Jean; “Le ministére des femmes dans l’Église ancienne”; La Maison Dieu 61; 1960; pp. 70-96; Gryson, Roger; Le ministère des femmes dans l'Église ancienne; Gembloux; 1972; Martimort, Aimé Georges; "A propos des ministéres feminins dans l'Église"; Bulletin de Littérature Ecclésiastique 74; 1973; pp. 103-108; Ruether, Rosemarie Radford; "Mothers of the Church: Ascetic Women in the Late Patristic Age"; en Rosemarie Radford Ruether y Eleanor Mclaughlin (eds.); Women of Spirit. Female Leadership in the Jewish and Christian Traditions; Nueva York; 1979; pp. 29-70 y pp. 71-98; y Madigan, Kevin y Osiek, Carolyne; Ordained Women in the Early Church. A Documentary History; Baltimore; 2005 (tr. esp. Teresa Arístegui Aguirre; ed. Verbo Divino; Estella (Navarra); 2006; pp. 31-49).
}

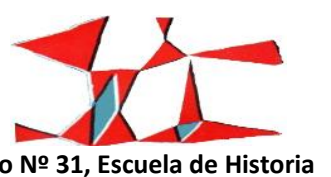


Ya en el siglo III (año 203), bajo Septimio Severo, fueron condenados en Cartago un grupo de catecúmenos, cuya protagonista indiscutible fue Vibia Perpetua y que, junto a otra mujer, la esclava Felicidad, dan nombre al documento que recoge las vicisitudes de su martirio entre un número de al menos seis personas (Saturo, Revocato, Saturnino, Secúndulo, Perpetua y Felicidad). Durante la persecución de Decio, en el 250, son mencionadas como compañeras de Pionio en el martirio Sabina y Asclepíades. En Alejandría de Egipto murieron quemadas Marcela y su hija Potamiena en una fecha dudosa entre el siglo III y el IV. En la misma ciudad fueron víctimas de la persecución de Decio: Quinta, que murió lapidada, Apolonia, quemada y Ammonaria, Mercuria y Dionisia decapitadas. El obispo Cipriano de Cartago proporciona en sus cartas un amplio número de nombres femeninos que confesaron su fe y murieron dando testimonio de ella: Cornelia, Emérita, María, Sabina, Espesina, Jenara, Dativa, Donata, Colónica y Sofía. Se refiere también a cuatro mujeres que murieron de hambre en la cárcel: Fortunata, Crédula, Hereda y Julia. En la "Pasión de Montano y Lucio", mártires durante la persecución de Valeriano, entre el 258 y 259, se narra la visión que Cuartilosia tuvo poco antes de morir y tres días después de haber sufrido el martirio su marido y su hijo. Por la misma época, en el relato del "Martirio de Santiago, Mariano y otros", se menciona al obispo Agapio que, gracias a sus oraciones consiguió que le siguieran en su calidad de mártir dos niñas muy queridas para él, llamadas Tertula y Antonia

Bajo la persecución de Diocleciano el número de mártires cristianas fue grande, en proporción a las dimensiones que alcanzó esa medida. Eusebio de Cesarea nos proporciona un relato pormenorizado de los mártires de Palestina en ese periodo. Así, sabemos que junto a Timoteo y Agapio fue condenada a ser pasto de las fieras Tecla; que Teodosia, una joven de apenas 18 años, fue arrojada al mar tras haber soportado terribles torturas; que la virgen Ennata fue arrastrada desnuda por Cesarea y después quemada viva . En el 304, durante la persecución de Maximiano, en Tesalónica fueron detenidas seis jóvenes, Ágape, Quionia, Casia, Filipa, Irene y Eutiquia, según se recoge en el Martirio; las dos primeras fueron quemadas vivas por negarse a sacrificar. Eutiquia se salvó por estar embarazada, siendo custodiada temporalmente en la cárcel. Irene terminó de igual forma que sus compañeras, tras serle descubiertos los textos sagrados que tenía escondidos, a pesar de su prohibición, y después de haber sido encerrada en un burdel, como forma de máximo escarnio. Por las mismas fechas fueron decapitadas en África tres muchachas, Máxima, Donatila y Segunda. Poco después, también en África fue víctima del martirio Crispina, mujer noble, casada y con hijos. Hay otros nombres femeninos especialmente famosos para nosotros, aunque en sus relatos se mezclan

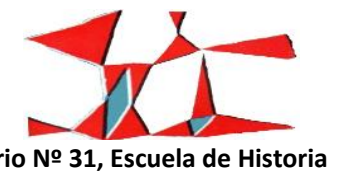




\section{EL PROTAGONISMO DE LAS MUJERES EN EL IMPERIO ROMANO. DEL POLITEÍSMO TRADICIONAL AL MONOTEÍSMO CRISTIANO}

abundantes datos legendarios y poéticos que cuestionan en gran medida la autenticidad de esos textos; en cualquier caso, están basados en hechos históricos que nos permiten tenerlos en cuenta. Nos referimos a Eulalia de Mérida, víctima del martirio a los 12 años, bajo el mandato de Maximiano que tenía a su cargo Hispania, cuya pasión nos describe el poeta cristiano Prudencio en forma de himno. También una niña llamada Inés, de apenas 13 años, fue decapitada en Roma durante la persecución de Diocleciano, después de haber sido expuesta en un burdel. Otras dos mártires hispanas Justa y Rufina, vendedoras de cerámica, murieron en Sevilla en tiempos de Diocleciano. A pesar de que sus Actas no fueron redactadas por un testigo de los hechos, sino por un autor del siglo VI o VII, este sí utilizó un documento contemporáneo del martirio.

Por tanto, podemos afirmar que el protagonismo de las primeras mártires cristianas es indiscutible, no sólo por su fuerte participación, sino también por la importancia de los papeles desempeñados en calidad de maestras, compañeras, líderes espirituales, intermediarias ante las autoridades terrenas, profetas y, en definitiva, ejemplo paradigmático para el resto de los fieles ${ }^{30}$.

\subsection{Tipología femenina}

Como contrapunto al modelo femenino pagano encarnado por la matrona romana, que acataba las reglas del mos maiorum y que era tan valorada por los paganos, los cristianos sintieron la necesidad de elaborar otro ideal de mujer apropiado a sus valores morales, y diferente del anterior. Fue un deliberado intento por crear los arquetipos a los que las mujeres cristianas habían de acomodar su formación y su comportamiento. A pesar de esa pretensión de diferenciarlas del patrón de conducta pagano, lo cierto es que ambos prototipos femeninos contaron con bastantes puntos en común. En el epitafio fúnebre de Turia, al que ya he aludido, se puede constatar esa coincidencia entre las cualidades atribuidas a la mujer ideal pagana y cristiana. Como el propio esposo reconoce, las virtudes domésticas eran comunes a todas las mujeres preocupadas por su buena reputación: honestidad, docilidad, carácter amable y alegre, dedicación a

\footnotetext{
30 Sobre la presencia de mujeres en los documentos martiriales cf. Mazzucco, Clementina; "E fui fatta maschio". La donna nel Cristianesimo primitivo; Turín; 1989; cap. V y VI; pp. 95-138; Eadem; "Figure di donne: la martire"; Atti del II Convegno nazionale di Studi sulla donna nel mondo antico; Turín; 1989; pp. 167-195; Consolino, Franca Ela; "Modelli di santità femminile nelle più antiche Passioni romane"; Augustinianum 24; 1984; pp. 83-113; Eadem; "La donna negli Acta Martyrum"; en Ugo Mattioli (ed.); La donna nel pensiero cristiano antico; Génova; 1992; pp. 95-117; y Torres, Juana; "El protagonismo de las primeras mártires cristianas"; en Isabel Gómez-Acebo (ed.); La Mujer en los orígenes del cristianismo; Madrid; 2005; pp.171-209.
}

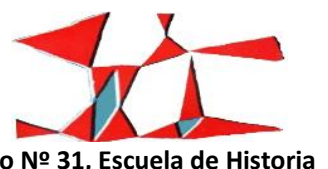

Anuario № 31, Escuela de Historia 
los trabajos de la lana, piedad sin superstición, recato en el vestir y sencillez en los aderezos, castidad, integridad de costumbres y fidelidad ${ }^{31}$.

Para verificar ese proceso de configuración del ideal de mujer cristiana tenemos que esperar al siglo IV, cuando tiene lugar la consolidación definitiva de la nueva religión y también la difusión del monacato, fenómeno de enorme trascendencia para el futuro de muchas mujeres cristianas. Los Padres de la Iglesia culminaron la formulación definitiva del nuevo prototipo femenino, que deseaban que fuera opuesto al pagano. Pero un modelo único podría resultar demasiado genérico; era preciso, por tanto, adaptar el ideal de mujer a las diferentes exigencias culturales y sociales de la época. Autores tan destacados como Jerónimo, Paulino de Nola, Gregorio de Nisa, Gregorio de Nacianzo, Juan Crisóstomo y Agustín, entre otros, proponen como exempla de la realización práctica de ese ideal, elaborado a nivel teórico, a mujeres reales con quienes les unían lazos de parentesco o de amistad. Todos ellos partían de la idea de la inferioridad connatural de la mujer respecto al hombre, pero esa condición podía ser superada a través de la ascesis, que la equiparaba convirtiéndola en mulier virilis ${ }^{32}$.

En esa adecuación del modelo femenino a la realidad social, el ideal místico de mujer cristiana se desdobla en varios tipos, configurados por las diferentes circunstancias de vida ${ }^{33}$. Se constituyen así cuatro status en los que encajarían las distintas categorías femeninas, cuatro prototipos que agrupan a todas las mujeres cristianas susceptibles de una valoración positiva: la virgo, la vidua, la mater y la diaconissa ${ }^{34}$. No

\footnotetext{
${ }^{31}$ Laud. Tur., Domestica bona pudicitiae, opsequi, comitatis, facilitatis, lanificiis tuis adsiduitatis, religionis sine superstitione, ornatus non conspiciendi, cultus modici... (I, 30-32); custodia pudicitiae (I, 10); morum probitas (I, 1); fidissuma (II, 43).

32 Sobre este tema cf. Giannarelli, Elena; "La mulier virilis ed i suoi sviluppi eterodossi"; en Elena Giannarelli; La Tipologia femminile nella biografia e nell'autobiografia cristiana del IVo secolo; Roma; 1980; pp. 86-88; Eadem; "La rivalutazione della donna, la donna virile e la filosofia"; en Elena Giannarelli; S. Gregorio di Nissa. La vita di S. Macrina; intr., tr., y not.; Milán; 1988; pp. 30-41; Aspegren, Kerstin; The Male Woman. A Feminine Ideal in the Early Church; Uppsala Women'Studies/Women in religion 4; 1990; Clark, Elisabeth; "Women and asceticism in Late Antiquity: The refusal of gender and status"; en Vincent L. Wimbush \& Richard Valantasis (eds.); Asceticism; Nueva York; 1995; pp. 33-48; y Pedregal, Amparo; "La mulier virilis como modelo de perfección en el cristianismo primitivo"; en Isabel Gómez Acebo (ed.); La mujer en los orígenes del cristianismo; Desclée de Brouwer; Bilbao; $2005 ;$ pp. $141-168$.

33 Me he ocupado ampliamente de la tipología femenina en el cristianismo antiguo y, especialmente en la literatura epistolar, como se puede comprobar en algunas publicaciones: Torres, Juana; "Tipología femenina en las epístolas de San Basilio: Principios teóricos y manifestación práctica"; Studia Historica 4-5; 1986-87; pp. 227-234; Eadem; La mujer en la epistolografía griega cristiana (ss. IV-V): tipología y praxis social; Servicio de Publicaciones. Universidad de Cantabria; 1990; Eadem; "Optima uxor/impudica et perversa mulier en la epistolografía griega cristiana (s. IV-V)"; Faventia 17; 1995; pp. 59-68; y Eadem; "Misoginia en la literatura patrística: Hacia una sistematización tipológica del ideal femenino"; en Juan José Pomer, Jordi Redondo y Ramón Torné (eds.); Misogínia, religió i pensament a la literatura del món antic $i$ la seua recepció; Hakkert; 2013; pp. 243-271.

${ }^{34} \mathrm{Cf}$. Schade, Kathrin; Frauen in der Spätantike: Status und Repräsentation, eine Untersuchung zur römischen und frühbyzantinen Bildniskunst; Mainz; 2003.
}

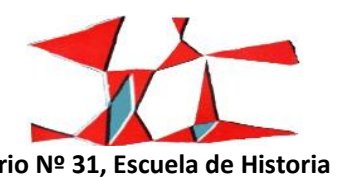




\section{EL PROTAGONISMO DE LAS MUJERES EN EL IMPERIO ROMANO. DEL POLITEÍSMO TRADICIONAL AL MONOTEÍSMO CRISTIANO}

pretendo realizar aquí una enumeración detallada de los rasgos característicos de cada uno de los status, tanto los comunes a todos ellos como los específicos, por tratarse de argumentos expuestos y desarrollados con profusión en la abundante bibliografía sobre los ministerios femeninos. Mi objetivo consiste en poner de manifiesto la especificidad de cada tipo mediante la constatación de esa escala de valores en mujeres reales, que concitaron en su persona todos los rasgos propios de la categoría femenina que representaban, o al menos así se los atribuyeron sus familiares y amigos, en un claro proceso de idealización. Para ello contamos con el testimonio que los Padres de la Iglesia nos han legado a propósito de las mujeres más emblemáticas y más cercanas a su persona. Presentaré una breve síntesis de cuatro figuras femeninas que constituyen el paradigma de los distintos prototipos: Macrina, hermana de Gregorio de Nisa y de Basilio el Grande, representa el modelo de la virgen; Melania iunior, nieta de Melania senior, constituye la figura ideal de la viuda; Olimpia, gran amiga de Juan Crisóstomo, es considerada el paradigma del diaconado femenino; y Mónica, la madre de Agustín, reúne todas las virtudes de la madre ideal.

a) Macrina iunior, originaria de la región de Capadocia, en Asia Menor, era hermana de Basilio de Cesarea y Gregorio de Nisa, ambos obispos y personajes emblemáticos en su época. Llevaba el nombre en recuerdo de su abuela, Macrina senior, una cristiana ilustre, y fue educada por su madre, Emmelia, sobre los textos de la Biblia y no sobre la cultura profana, totalmente inconveniente para la muchacha ${ }^{35}$. Estaba destinada a casarse al cumplir los 12 años, pero la muerte sorprendió a su prometido antes de celebrarse el matrimonio y, a partir de ese momento, Macrina decidió orientarse hacia la vida monástica y no separarse de su madre, permaneciendo en el hogar.

Esa decisión de la joven concuerda con las primeras manifestaciones en Oriente del ascetismo femenino y, más concretamente, de las vírgenes ${ }^{36}$. A diferencia de otras tradiciones anteriores, especialmente la judía, que otorgaban una valoración negativa a la virginidad, por cuanto implicaba la renuncia a perpetuar la especie, el cristianismo les concedió una enorme consideración y un papel preeminente frente a los

\footnotetext{
${ }^{35}$ La fuente fundamental para conocer información sobre esta mujer es la "Vida de Macrina”, escrita por Gregorio de Nisa. La edición y traducción francesa fue llevada a cabo por Maraval, Pierre; Saint Grégoire de Nysse. La vie de Sainte Macrine; París; 1971.

36 Diversas fuentes atestiguan que durante los primeros siglos del cristianismo la vida de las vírgenes transcurría en un ambiente familiar, y así continuó hasta bien avanzado el siglo IV. Cf. Metz, René; La consécration des vierges dans l'Église romaine. Étude d'histoire de la liturgie; París; 1954; Elm, Susanna; "Virgins of God": The Making of Asceticism in Late Antiquity; Oxford; 1994; y Cooper, Kate; The Virgin and the Bride: Idealized Womanhood in Late Antiquity; Cambridge (MA); 1996.
}

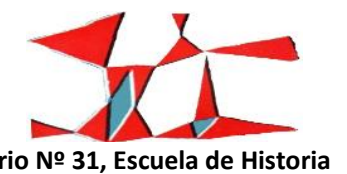


restantes status femeninos. En un principio la preferencia de la virginidad en el mundo cristiano estuvo motivada por la perspectiva escatológica dominante, que creía próximo el fin del mundo, pero posteriormente prevalecieron otros principios platónicos y estoicos, que encontraron su justificación en los dos ejemplos paradigmáticos de Cristo y María, y en la interpretación restrictiva de algunos pasajes bíblicos como Pablo, I Cor. 7, y Mateo 19, 12. Fue en el siglo IV cuando se inició la reglamentación del ordo virginum, estableciendo unos requisitos y creando una gradación para entrar a formar parte del mismo. Las pautas generales eran las siguientes: La elección debía ser voluntaria y libre, sin ningún tipo de presión; se exigía la integridad física pero también la del alma, la santidad espiritual, sin la cual la primera carecía de valor; tenían que formular la promesa solemne de renunciar al matrimonio y reunir una serie de cualidades como la caridad, misericordia, bondad, humildad, etc. Tras el voto de virginidad y de renuncia al mundo, las jóvenes eran consagradas en una ceremonia solemne presidida por el obispo, pero no recibían la ordenación o imposición de manos (cheirotonía), exclusiva de los miembros del clero. Las vírgenes poseían un puesto privilegiado sobre las viudas y los laicos, pero no eran consideradas miembros del clero, a diferencia de las diaconisas. Su único campo de acción se circunscribió a las comunidades ascéticas, donde ese status privilegiado les permitía acceder a los ambientes intelectuales y a los estudios teológicos y filosóficos.

En la siguiente fase se incorporó también la madre de Macrina, tras abandonar el lujo y el bienestar propios de su clase, y se adaptó a la forma de vida de las otras vírgenes que convivían con ellas. La casa se transformó en un monasterio en el que fueron eliminadas las diferencias de clase, convirtiéndose todas, esclavas y señoras, en hermanas que compartían mesa, lecho y medios de subsistencia. Su existencia transcurría en medio de las oraciones y la entonación de himnos, día y noche. Así pasó un largo período de tiempo hasta que, por las mismas fechas, se produjeron acontecimientos de extraordinaria importancia para la virgen, como el fallecimiento de la madre, la consagración de su hermano Basilio el Grande como obispo de Cesarea y la ordenación de Pedro como sacerdote ${ }^{37}$. Sólo 8 años más tarde murió Basilio, provocando en Gregorio de Nisa y en Macrina un tremendo dolor, con el que ya estaban familiarizados por haber sufrido la pérdida de su hermano Naucracio y de su madre. Poco tiempo después, un año según el autor de la biografía, murió Macrina.

\footnotetext{
${ }^{37}$ En el 370 Basilio fue elegido obispo, al año siguiente murió Emmelia y entre el 370 y el 375 fue ordenado Pedro, llegando a ser
} obispo de Sebaste.

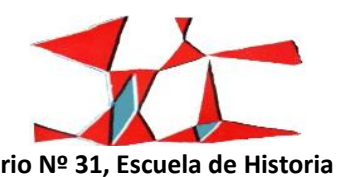




\section{EL PROTAGONISMO DE LAS MUJERES EN EL IMPERIO ROMANO. DEL POLITEÍSMO TRADICIONAL AL MONOTEÍSMO CRISTIANO}

b) A Melania iunior el nombre le vino dado por su abuela, Melania senior, conocida por la historia debido a su renuncia al mundo, a su fortuna y a su familia, cuando enviudó a muy temprana edad. A pesar de su temprana inclinación por la virginidad, sus padres la casaron, para asegurar la transmisión de un inmenso patrimonio, con Piniano, hijo de un ex-Prefecto de Roma ${ }^{38}$. La pérdida de sus dos hijos, que murieron siendo muy pequeños, impulsaron a ambos esposos a comprometerse definitivamente en la castidad. Tras vender sus propiedades, dispersas por las provincias del Imperio, en el 410 , tras la toma de la ciudad por Alarico, abandonaron Roma Pininano, Melania y su madre Albina y se dirigieron a África. Vivieron en Tagaste siete años en compañía del obispo Alipio, amigo de Agustín de Hipona. La asceta pasó ese periodo entregada al estudio de la Biblia y de los textos monásticos, así como a su transcripción, como nos dice su biógrafo:

Escribía con mucho talento y sin faltas sobre pequeños cuadernos... Caligrafiaba textos para satisfacer sus necesidades vitales y vendía los ejemplares escritos con su propia mano a los santos monjes... Leía con tal asiduidad los tratados de los santos que ningún libro que ella pudiera encontrar le resultaba desconocido (Vit. Melan. 23 y 26$)^{39 .}$

A continuación decidieron ir en peregrinación a los Santos Lugares, objetivo común de todos los ascetas de la época, y llegaron a Jerusalén pasando por Alejandría. Allí se instalaron definitivamente, y Melania se encerró en una celda ubicada en el Monte de los Olivos, de donde salió sólo a la muerte de su madre, que fue enterrada en ese lugar, y donde hizo construir a continuación un monasterio femenino del que se convirtió en preceptora y directora espiritual ${ }^{40}$. Piniano por su parte vivía en compañía de otros hombres que, al igual que él, habían abrazado la vida monástica, y así transcurrió su existencia hasta el año 432 en que murió. Fue enterrado en la capilla que a tal efecto había hecho construir Melania y que estaba dedicada a los apóstoles. A partir de ese momento se convirtió en viuda de pleno derecho, pero en realidad llevaba mucho tiempo comportándose como tal y desarrollando actividades propias de esa institución. Los antiguos griegos, judíos y romanos no concedieron a la viudez la importancia que le reservó el cristianismo.

\footnotetext{
${ }^{38}$ Nos proporcionan información sobre la vida de Melania iunior una biografía compuesta por Geroncio, sacerdote, confidente y amigo de la asceta a partir de su estancia en Jerusalén, además de referencias varias en las fuentes patrísticas de la época como la "Historia Lausiaca" de Paladio de Helenópolis y la Correspondencia de Paulino de Nola, Jerónimo y Agustín.

${ }^{39}$ Gorce, Denys; Vie de Sainte Mélanie; ed., tr. y not.; Sources Chrétiennes; París; 1962.

40 Sería una especie de abadesa, al igual que otras santas mujeres fundadoras de monasterios.
}

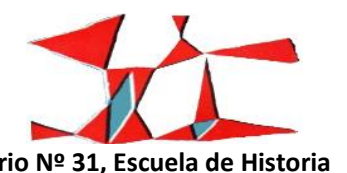


El grupo de las viudas fue una categoría femenina favorecida siempre por la Iglesia como principal beneficiaria de la caridad cristiana, debido a la situación de necesidad e indefensión en que quedaban frecuentemente las mujeres al perder a sus maridos. En los inicios del cristianismo no era un cargo eclesiástico, sino un estado de vida, pero, a partir del siglo IV se convirtió en una institución de la Iglesia, con unas funciones claramente definidas. Las viudas no pertenecían al clero, al igual que el grupo de las vírgenes, y cuando manifestaban su voto de continencia no eran ordenadas. Sus obligaciones poseían un marcado carácter asistencial, debiendo fundamentalmente practicar obras de caridad y consagrarse a la vida contemplativa y a la oración ${ }^{41}$. El desarrollo de la vida monástica contribuyó a la progresiva desaparición de la institución de las viudas, porque el ideal que hasta entonces se había desarrollado en el mundo, empezó a realizarse en el ámbito de los monasterios, como acabamos de ver, y las actividades propias de esas mujeres fueron en adelante desempeñadas por las diaconisas, función que suplantó a las viudas. Precisamente, en el ejercicio de la caridad y del ascetismo encontraron muchas mujeres una vía para promocionarse y adquirir un prestigio que de otra forma les estaba negado, pues disfrutaron así de una mayor libertad de movimientos y de actuación.

En el 436 viajó a Constantinopla y desplegó su acción en favor de la ortodoxia y del ascetismo en la capital y en la Corte, en estrecha relación con la emperatriz Eudocia, la mujer de Teodosio II, y con su hija Eudoxia, futura esposa del emperador Valentiniano III. Volvió a Jerusalén donde completó sus fundaciones monásticas, al menos dos femeninas y una masculina, e hizo construir un martyrion, o santuario en honor de los mártires. Melania falleció a finales del 439.

c) En Constantinopla, a mediados del siglo IV, y en una familia noble y extraordinariamente rica nació Olimpia ${ }^{42}$. Su abuelo fue Flavio Ablabio, prefecto del Pretorio de Oriente y cónsul bajo Constantino, que

\footnotetext{
${ }^{41}$ Sobre el ordo viduarum, entre los numerosos estudios modernos cf. Danielou, Jean; "Le ministère des femmes dans l’Église ancienne"; La Maison Dieu 61; 1960; pp. 70-96; Davies, John Grant; "Deacons, deaconesses and the minor orders in the patristic period"; Journal of Ecclesiastical History 16; 1963; pp. 1-15; Nazzaro, Antonio Vincenzo; "La vedovanza nel cristianesimo antico", Annali della Facoltà di Lettere e Filosofia della Università di Napoli 26; 1983-84; pp. 127-130; Idem; "Figure di donne cristiane: la vedova"; en Renato Uglione (ed.); Atti del II convegno nazionale di studi su La donna nel mondo antico; Turín; 1989; pp. 197-219; Rosa B. Bruno Siola; "Viduae e coetus viduarum nella chiesa primitiva e nella norma dei primi imperatori cristiani"; en Atti dell'Accademia romanistica costantiniana. VIII Convegno internazionale; Nápoles; 1990; pp. 367-426; Bremmer, Jan; "Pauper or patroness: The widow in the early Christian Church"; en Idem \& Laurens Van den Bosch (eds.); Between Poverty and the Pyre: Moments in the History of Widowhood; Londres-Nueva York; 1995; pp. 31-57; y Barcellona, Rossana; "Le vedove cristiane tra i Padri e le norme"; en Johannes Grohe, Jerónimo Leal \& Vito Reale (eds.); I Padri e le scuole teologiche nei concili; Atti del VII Simposio Internazionale della Facoltà di Teologia; Ciudad del Vaticano; 2006; pp. 181-199.

42 Nos dan información sobre esta mujer las 17 epístolas de Juan Crisóstomo a Olimpia, el "Diálogo sobre la vida de Juan Crisóstomo" y la "Historia Lausiaca" de Paladio de Helenópolis, la "Vida anónima de Olimpia” y las “Historias eclesiásticas” de Sócrates y Sozomeno.
}

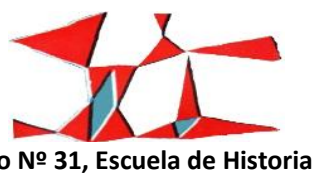

Anuario № 31, Escuela de Historia

Facultad de Humanidades y Artes (Universidad Nacional de Rosario), 2019 ISSN 1853-8835 


\section{EL PROTAGONISMO DE LAS MUJERES EN EL IMPERIO ROMANO. DEL POLITEÍSMO TRADICIONAL AL MONOTEÍSMO CRISTIANO}

profesaba la religión cristiana. Desde temprana edad se sintió inclinada al ascetismo, como nos lo explica Juan Crisóstomo en una de las cartas: "Esta ascesis era practicada desde la más tierna infancia, sin tener maestros para enseñártela, escandalizabas a un gran número de gente y, desde el punto de vista espiritual, pasaste de un medio impío a la verdad, tratándose además de un cuerpo femenino y delicado a causa de la situación y del lujo de tus padres (Ep. ad Olimp., 8, 5c) ${ }^{43}$ pero las expectativas de Procopio, su tutor, eran otras. A instancias del emperador Teodosio el Grande, le eligieron como esposo a Nebridio, prefecto de la ciudad de Constantinopla en el 386, y pariente de la emperatriz Aelia Flacilla. El matrimonio duró muy poco, unos meses según las fuentes, debido al fallecimiento del esposo. A pesar de las presiones de unos y otros para que la joven renunciara a sus aspiraciones ascéticas y consintiera en volver a casarse, se mantuvo firme en su postura. Finalmente, el obispo de Constantinopla Nectario la consagró como diaconisa a los 30 años, en contra de la normativa eclesiástica que establecía una edad no inferior a los $60^{44}$.

La institución del diaconado femenino debió surgir en la primera mitad del siglo III en la zona oriental del Imperio, puesto que el primer texto 12 que la presenta en una posición paralela al diaconado masculino es la Didascalia de los Apóstoles, obra de carácter normativo escrita en griego por esa época. En el siglo IV las Constituciones Apostólicas, que refundieron la Didascalia en los 6 primeros libros, añadieron ciertas precisiones y ampliaron las tareas atribuidas a las diaconisas. Éstas debían ser elegidas entre las vírgenes o las viudas casadas una sola vez (univirae). Sus tareas incluían una doble misión: pastoral y litúrgica; la primera consistía en la asistencia y los cuidados a domicilio de las mujeres enfermas o incapacitadas, para evitar las críticas de los paganos. Podían desempeñar también el papel de intermediarias entre las mujeres y los hombres de la jerarquía eclesiástica, siendo testigos de sus conversaciones para asegurar así la decencia (Const. Ap. 2, 26, 6; 3, 19,1; 6, 17,4). La misión litúrgica tenía lugar durante la ceremonia del bautismo, en la que ungían el cuerpo de las mujeres antes de sumergirse en el agua y las recogían para secarlas al salir, por la inconveniencia de que su desnudez fuera contemplada por los hombres. También debían recibir a las mujeres en las asambleas litúrgicas, cuidando de que encontraran un lugar en la iglesia y de que las más

\footnotetext{
${ }^{43}$ La edición más reciente es la de Malingrey, Anne Marie; Jean Chrysostome. Lettres a Olympias. Vie anonyme d'Olympias; intr., ed. tr. y not.; París; 1968.

${ }^{44}$ Cf. Cod. Theod. XVI, 2, 27; y Torres, Juana; "Mulieres diaconissae. Ejemplos paradigmáticos en la Iglesia oriental de los ss. IV-V"; Diakonía, Diaconiae, Diaconato. Semantica e Storia nei Padri della Chiesa; Studia Ephemeridis Augustinianum 117; Roma; 2010; pp. 625-638
}

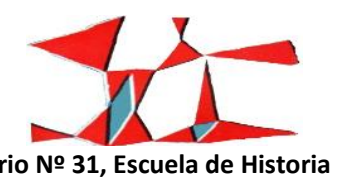


jóvenes cedieran su sitio a las de más edad. Esas eran sus funciones, estando excluidas de las propias de los diáconos como asistir al obispo y al sacerdote en el altar, y distribuir la comunión. La institución de las diaconisas formaba parte del clero y, como los restantes miembros, recibían la ordenación conferida por la imposición de manos (cheirotonía) y la oración del obispo. En cambio las viudas y las vírgenes, los otros ordines femeninos, no eran ordenadas (Const. Ap. 2, 58, 4-6; 3, 16, 4; 8,19, 2; 24,2; 25, 2. Didasc. Ap. 3, 12, 3). Frente a las regiones de lengua griega, en las iglesias de lengua latina la institución de las diaconisas no apareció hasta el siglo V, y Roma la aceptó a finales del siglo VIII. Además, se trató de una función honorífica más que de un ministerio propiamente dicho ${ }^{45}$.

Una vez ordenada diaconisa, Olimpia se convirtió en la benefactora de los pobres y necesitados, pero, sobre todo, de la Iglesia de Constantinopla, ya que los monjes y obispos fueron sus principales beneficiarios. A partir del nombramiento de Juan Crisóstomo como sucesor de Nectario en el episcopado (397) y del encuentro y la amistad con ella, el obispo puso fin al descontrol de la actividad caritativa de la diaconisa, pues una especie de paroxismo caritativo la había llevado a dilapidar casi totalmente su fortuna. Lo que quedaba de sus bienes fue puesto a disposición de la Iglesia constantinopolitana y de su obispo, con lo cual se fundaron hospitales, hospicios, asilos, así como el monasterio femenino que Olimpia ordenó construir junto a la Iglesia de Santa Sofía y a la casa episcopal. A esta fundación monástica, la primera de la que tenemos noticia en Constantinopla, incorporó a sus 50 criadas y se sumaron igualmente parientes y amigas aristócratas que llevarían consigo también a su servidumbre femenina, llegando a alcanzar el número de 250 miembros. Ignoramos el funcionamiento de la comunidad, pues los escasos datos que nos proporciona su biografía se limitan a la práctica de la ascesis, la abstinencia, los cantos y oraciones, el ejercicio de la caridad y el retiro, sin relacionarse con hombres o mujeres, a excepción de su director espiritual, Juan Crisóstomo. Este tipo de monacato femenino aristocrático nos evoca el que surgió en Roma unos años antes en torno a Marcela y otras mujeres de su clase, cuyo director fue Jerónimo, y que tuvo su continuación en el que Paula fundó en

\footnotetext{
45 Cf. Ferrari, Giuseppe; "Le diaconesse nella tradizione orientale"; Oriente Christiano 14; 1974; pp. 28-50; Vagaggini, Cipriano; "L'ordinazione delle diaconesse nella tradizione greca e bizantina"; Orientalia Christiana Periodica 40; 1974; pp. 146-189; y Martimort, Aimé Georges; “A propos des ministères féminins dans l'Église”; Bulletin de Littérature Ecclésiastique 74; 1973 ; pp. 103-108.
}

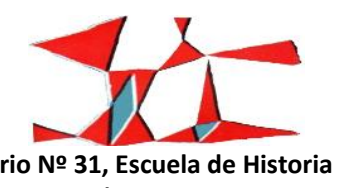




\section{EL PROTAGONISMO DE LAS MUJERES EN EL IMPERIO ROMANO. DEL POLITEÍSMO TRADICIONAL AL MONOTEÍSMO CRISTIANO}

Belén 13. Además, el paralelismo entre las relaciones de Juan con Olimpia y las de Jerónimo con Paula resulta evidente, como se ha señalado en la bibliografía sobre ese tema ${ }^{46}$.

Pero el obispo cayó en desgracia, víctima de la confabulación de ciertos individuos, como Teófilo de Alejandría, con la casa imperial y sobre todo con la emperatriz Eudoxia, y el asunto desembocó en la deposición y exilio de Juan Crisóstomo en el $404^{47}$. A partir de ese momento Olimpia desplegó su capacidad de influencia ante las autoridades civiles y eclesiásticas para intentar conseguir, sin éxito, la vuelta de su amigo; fue víctima de persecuciones por parte de los enemigos de Juan, que la obligaron a comparecer en juicio ante el prefecto y posteriormente a exiliarse a Nicomedia hasta su muerte. Aunque la comunicación entre ambos fue fluida e incluso abundante, teniendo en cuenta las dificultades del transporte en esa época, el desánimo y el abandono fueron haciendo mella en el cuerpo y en el ánimo de la diaconisa hasta que terminaron con su vida. La correspondencia que ambos intercambiaron durante el exilio del obispo constituye un testimonio extraordinario del sufrimiento de los dos amigos ${ }^{48}$.

d) Mónica, la madre de Agustín, representa el último de los cuatro prototipos. A diferencia de las otras instituciones femeninas, la mulier maritata supone una mayor continuidad con respecto a la tradición anterior, adaptándose simplemente a los aspectos específicamente cristianos. Si la virgen, la diaconisa y la viuda fueron arquetipos en gran medida originales del cristianismo, la esposa y madre encuentra su modelo en la tradición pagana y en el Antiguo Testamento, y se perpetúa con la nueva religión. La mujer casada se realiza plenamente en el ámbito del núcleo familiar, en esa doble vertiente de esposa y madre, pero en contacto con el mundo, como una variante de los otros status que fundamentalmente desarrollaban

\footnotetext{
${ }^{46}$ Esos textos han sido objeto de estudio por parte de diversos historiadores, como Mathews, John; Western Aristocracies and Imperial Court, A.D. 364-425; Oxford; 1975; Clark, Elisabeth A.; Jerome, Chrysostome and Friends. Essays and Translations; Nueva York-Toronto 112; 1979; Consolino, Franca Ela; "Modelli di comportamento e modi di santificazione per l'aristocrazia femminile d'Occidente"; en Andrea Giardina (ed.); Società romana e impero tardoantico; vol. I; Roma-Bari; 1986; pp. 273-306 y pp. 684-699; y Marcos, Mar; Las mujeres de la aristocracia senatorial en la Roma del Bajo Imperio (312-410); Servicio de Publicaciones. Universidad de Cantabria; 1990.

${ }^{47}$ Esos acontecimientos han suscitado el interés de varios investigadores, entre otros Van Ommeslaeghe, Florent; "Jean Chrysostome en conflict avec l'impératrice Eudoxie. Le dossier et les origines d'une légende"; Analecta Bollandiana 97; 1979; pp. 131-159; y Torres, Juana; "Concerning John Chrysostom: Collectio Avellana 38 and his controversy in the West"; en Alexander Evers (ed.); Emperors, Bishops, Senators. The significance of the Collectio Avellana 367-553 AD; Peeters; (en prensa).

48 Cf. Torrres, Juana; La mujer en la epistolografía griega cristiana (ss. IV-V): tipología y praxis social; Servicio de Publicaciones. Universidad de Cantabria; 1990; y Marcos, Mar; “Le lettere di Giovanni Crisostomo a Olimpiade: Frammenti di un’amicizia”; en Ramón Teja; Olimpiade la diaconessa, Donne d’Oriente e d’Occidente; Milán; 1996; pp. 113-146.
}

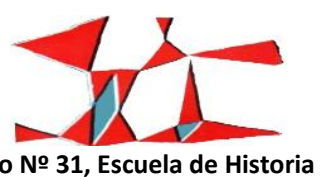


su actividad en el interior de un monasterio ${ }^{49}$. En realidad la función de la maternidad justifica el matrimonio, pues tradicionalmente se concibió la procreación como su razón de ser y fue considerada por los Padres de la Iglesia como su fin primordial. Todos los moralistas cristianos aceptaron el matrimonio en calidad de mal menor, por tratarse de una institución establecida por Dios, pero lo consideraron un obstáculo para la entrega y dedicación completa al culto divino ${ }^{50}$. Debido a la escasa valoración otorgada al matrimonio por los escritores cristianos, frente a la alta estima concedida a la virginidad, se desarrolló en muchas de sus obras un argumento, ya utilizado por los filósofos paganos y especialmente por los estoicos, que llegará a constituir el lugar común de las molestiae nuptiarum. Este tópico consistía en poner de manifiesto las múltiples desventajas e inconvenientes que acarreaba la vida conyugal, frente a los escasos beneficios, resaltando en cambio los innumerables méritos y recompensas de los célibes ${ }^{51}$.

Si la realización plena de la mujer casada abarcaba una doble función, la de esposa y madre, su continuidad dentro del cristianismo implicó una tercera faceta relacionada con Dios. Así, la tipología de la mulier maritata se configuró a través de una triple dimensión que afecta a su relación con Dios, como famula Dei, con su esposo en el papel de uxor y con sus hijos en calidad de mater $^{52}$. En el cumplimiento de estas tareas hay que encuadrar la figura emblemática de Mónica, madre Agustín de Hipona. Las noticias que poseemos sobre ella aparecen básicamente recogidas por su hijo en "Las Confesiones". Nació en el seno de una familia piadosa y fue educada en los dogmas del cristianismo, pero su esposo Patricio era pagano. Ella intentó convertirle a través del ejemplo de sus sobrias y púdicas costumbres y manifestándole en todo momento respeto y sumisión, objetivo que logró al morir él, siendo muy joven. De esa forma Mónica se encontró libre para entregarse a la oración y para educar en la fe a su hijo Agustín, como verdaderamente anhelaba. Pero durante la vida de Patricio adoptó una actitud de sumisión, prudencia y tolerancia que

\footnotetext{
${ }^{49}$ Sobre la dicotomía entre la esposa ideal y su contraria en las epístolas de los Padres griegos cf. Torres, Juana; “Optima uxor/impudica et perversa mulier en la epistolografía griega cristiana (s. IV-V)"; Faventia 17; 1995; pp. 59-68.

50 Por citar solo alguno de los numerosos trabajos sobre el matrimonio cristiano de los primeros siglos, cf. Crouzel, Henri; "Le mariage des chrétiens aux premiers siècles de l'Église”; Esprit et Vie 93; 1973; pp. 87-91; Cantalemassa, Raniero (ed.); Etica sessuale e matrimonio nel cristianesimo delle origini; Milán; 1976; Sargenti, Manlio; "Matrimonio cristiano e società pagana"; Studia et Documenta Historiae et Iuris 51; 1985; pp. 367-391; Munier, Charles; Mariage et virginité dans l'Église ancienne (ler-llle siècle); Traditio Christiana 6; Berna; 1987.

${ }^{51}$ Cf. Torres, Juana; "El tópico de las molestiae nuptiarum en la literatura cristiana antigua"; Studia Ephemeridis Augustinianum 50; La Narrativa cristiana antica. Codici narrativi, Strutture formali, Schemi retorici; XXIII Incontro di Studiosi dell'antichità cristiana Roma; 1995; pp. 101-115.

52 Reynolds, Philip Lyndon; Marriage in the Western Church: The Christianization of Marriage during the Patristic and Early Medieval Periods; Leiden; 1994; Aubin, Melissa; "More apparent than real? Questioning the difference in marital age between Christian and non-Christian women of Rome during the third and fourth centuries"; Ancient History Bulletin 14; 2000; pp. 1-13.
}

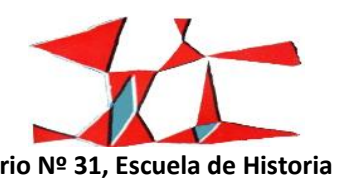




\section{EL PROTAGONISMO DE LAS MUJERES EN EL IMPERIO ROMANO. DEL POLITEÍSMO TRADICIONAL AL MONOTEÍSMO CRISTIANO}

despertaba sorpresa y admiración entre las otras matronas, debido al carácter colérico del esposo. El texto que recoge esta información constituye un documento de excepción como testimonio de los malos tratos infligidos por los maridos a sus esposas ya en esa época de finales del siglo IV ${ }^{53}$.

Resume Agustín las virtudes de su madre en pocas líneas cuando afirma: "Había sido mujer de un solo varón -unius viri uxor-, había cumplido con sus padres, había gobernado su casa piadosamente y tenía el testimonio de las buenas obras, y había nutrido a sus hijos, pariéndolos tantas veces cuantas los veía apartarse de Dios" (Confess. IX, 9,22). Efectivamente, una de las mayores preocupaciones en la vida de Mónica fue convertir al cristianismo a su hijo Agustín, objetivo que le ocasionó terribles disgustos, pero todos sus esfuerzos se vieron al final compensados, cuando por fin se bautizó y despreció la felicidad terrena, como le hizo saber a su madre en el lecho de muerte. Por tanto, esa mujer cumplió a la perfección con las tres funciones que comportaba su status: amor y devoción a Dios y a los asuntos sagrados, representados en la cualidad de la pietas; sumisión y respeto al marido como primera autoridad, para que reinara la paz y la armonía en la familia, llevando una vida marcada por la castidad o pudicitia; y en tercer lugar el cuidado y educación cristiana de sus hijos, anteponiendo el alimento espiritual al material, como optima mater. Todas esas cualidades las recoge con precisión Agustín al afirmar "Nos acompañaba mi madre con hábito de mujer, fe de varón, seguridad de anciana, amor de madre y piedad cristiana" ${ }^{54}$. Murió en Ostia, camino de su tierra, a los 56 años, y sus restos fueron depositados junto a los de su marido, tal como era su deseo.

\subsection{Protagonismo de las mujeres. Algunos ejemplos}

Las fuentes literarias y epigráficas nos informan de que algunas mujeres participaron activamente en la política eclesiástica de los primeros siglos, desempeñando tareas importantes. Pese a no existir un reconocimiento oficial, la documentación a nuestro alcance proporciona testimonios sobre la intervención ejercida por algunas mujeres, y también sobre la gran influencia que desplegaron en cuestiones trascendentales para la Iglesia. Las elecciones y deposiciones de obispos, la orientación doctrinal o la difusión

\footnotetext{
${ }^{53}$ Agustín, Confess. IX, 9, 19 (Custodio Vega, Ángel; Obras de San Agustín. Las Confesiones; ed. y tr.; Madrid; 1963) Sobre la violencia doméstica en esa época cf., entre otros, Schroeder, Joy A; "John Chrysostom's Critique of Spousal Violence"; Journal of Early Christian Studies 12/4; Johns Hopkins University Press; 2004; pp. 413-442; y Dossey, Leslie; "Wife beating and manliness in Late Antiquity"; Past and Present 199; 2008; pp. 2-40.

${ }^{54}$ Aug. Confess. IX, 4,8: Matre adhaerente nobis muliebri habitu, virili fide, anili securitate, materna caritate, cristiana pietate.
}

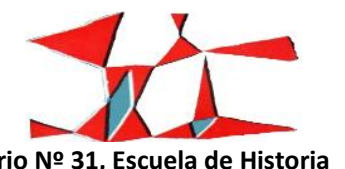


y consolidación del movimiento ascético dependieron en gran medida de ellas. Las prohibiciones más importantes, como la enseñanza y el sacerdocio, no impidieron en absoluto a ciertas mujeres desempeñar un enorme poder, aunque de carácter extra-oficial. Son muchos los ejemplos y por ello voy a referirme solamente a los casos más significativos ${ }^{55}$. Se observa que la mayoría de esas mujeres pertenecían a la élite social y política; eran ricas, cultas y tenían gran influencia sobre sus parientes masculinos. Muchas de ellas eran expertas en teología, por lo cual resultaría muy difícil impedir su participación en las disputas teológicas, además, sus recursos y autoridad harían imposible excluirlas de la organización eclesiástica. Precisamente, sabemos que las emperatrices de la familia teodosiana desempeñaron un gran protagonismo en los diferentes concilios: Elia Flacilla en el de Constantinopla del 381, como fiel guardiana de la doctrina nicena, evitó que su esposo Teodosio I se entrevistara con Eunomio de Cízico, de orientación neo-arriana, por temor a que le persuadiera e indujera a cambiar de idea al emperador. Eudocia, monofisita, y su hermana Pulqueria influyeron sobre Teodosio II en el concilio de Éfeso (431); en el de Calcedonia (451) Pulqueria, junto a Marciano, tuvo un papel importante en la victoria anti-monofisita. Y Gala Placidia intervino en el debate pelagianista así como en el cisma de la iglesia de Roma del 419, enviando cartas a diversos obispos para que acudieran al sínodo de Espoleto y terminaran con el conflicto ${ }^{56}$.

Además de las emperatrices, otras mujeres ejercieron gran influencia en la política eclesiástica, como vamos a exponer a continuación:

a) Los arrianos de Sirmio enfrentaron a vírgenes exaltadas contra Ambrosio de Milán, y casi acaban con su, vida cuando intentó imponerles al obispo niceno Antemio. Ambrosio, a su vez, se rodeó después de un numeroso grupo de vírgenes que le proporcionaban poder y prestigio ${ }^{57}$.

\footnotetext{
${ }^{55}$ Sobre la influencia de las mujeres en ámbito eclesiástico cf. Torres, Juana; "Minorías poderosas. Participación femenina en la política eclesiástica de los primeros siglos"; en Gonzalo Bravo y Raúl González Salinero (eds.); Minorías y Sectas en el Mundo romano; Signifer Libros; Madrid; 2006; pp. 93-105.

56 Cf., entre otros, Pietri, Charles; “Esquisse de conclusion. L'Aristocratie chètienne entre Jean de Constantinople et Augustin d'Hippone"; en Kannengiesser, Charles (ed.); Jean Chrysostome et Augustin; París; 1975; pp. 283-305; Holum, Kenneth H.; Theodosian Empresses. Women and Imperial Dominion in Late Antiquity; Berkeley; 1982; Consolino, Franca Ela; "Modelli di comportamento e modi di santificazione per l'aristocrazia femminile d'Occidente"; en Andrea Giardina (ed.); Società romana e impero tardo-antico I; Roma/Bari; 1988; pp. 273-306; y Teja, Ramón; “Feminismo, religión y política en la Antigüedad tardía”; en Ramón Teja; Emperadores, obispos, monjes y mujeres. Protagonistas del cristianismo antiguo; Madrid; 1999; pp. 215-231.

57 Paulino, Vida de Ambrosio, 11. Cf. Lizzi, Rita; "Una società esortata al ascetismo: misure legislative e motivazioni economiche nel IV-V secolo d. C."; Studi Storici 30; 1989; pp. 137-138.
}

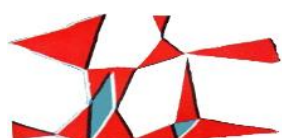

Anuario № 31, Escuela de Historia 


\section{EL PROTAGONISMO DE LAS MUJERES EN EL IMPERIO ROMANO. DEL POLITEÍSMO TRADICIONAL AL MONOTEÍSMO CRISTIANO}

b) Juan Crisóstomo experimentó las ventajas e inconvenientes del poder asumido por las mujeres en ámbito eclesiástico. Entre otros factores, los sucesivos conflictos que protagonizó en Constantinopla con la emperatriz Eudoxia y con su grupo de poderosas viudas, Marsa, Castricia y Eugrafia, le valieron su deposición y exilio hasta el final de sus días. Pero también disfrutó del apoyo y amistad incondicional de otras mujeres de la aristocracia, tanto durante su episcopado como después en el destierro, recibiendo ayuda material, diplomática y espiritual por parte de la diaconisa Olimpia, de sus compañeras y de numerosas corresponsales que secundaron su causa ${ }^{58}$.

c) También se implicaron en las disputas teológicas las mujeres que, por su cultura y formación religiosa, estuvieran capacitadas para ello. Marcela, gran amiga de Jerónimo, es presentada como defensora de la ortodoxia contra los origenistas y adquirió tales conocimientos de las Escrituras que, cuando se planteaba alguna duda, se recurría a ella para resolverla.

d) Melania senior apoyaba a Rufino de Aquileya, que era atacado por ser el traductor de Orígenes, y durante la persecución antenicena de Valente había proporcionado con sus bienes el sustento a obispos y sacerdotes ortodoxos deportados a Palestina. Después en su monasterio de Jerusalén acogió durante 27 años a obispos, monjes y vírgenes que pasaban por allí.

e) Melania iunior desplegó todos sus conocimientos para luchar contra la doctrina de Nestorio durante su estancia en Constantinopla, y su biógrafo Geroncio nos describe esa actividad: "También venían a discutir con la santa madre sobre la fe ortodoxa muchas mujeres de senadores y de hombres muy distinguidos por su elocuencia. Y ésta no cesaba de hablar sobre teología de la mañana a la noche reconduciendo hacia la fe ortodoxa a muchos extraviados... (Vida de Macrina, 54.).

f) A pesar de que la enseñanza en público estaba prohibida a las mujeres, su actividad como educadoras y transmisoras de los principios cristianos se desarrollaba en el interior del hogar. En ese aspecto, por tanto, sí que tuvieron una intervención decisiva. Un testimonio ilustrativo de la ascendencia femenina entre los parientes del otro sexo nos lo proporciona Basilio de Cesarea en una epístola destinada a los

\footnotetext{
58 Entre los diversos estudios cf. Van Ommeslaeghe, Florent; "Jean Chrysostome en conflicto avec l'emperatrice Eudoxie. Le dossier et les origines d'une légende"; Analecta Bollandiana 97; 1979; pp. 131-159; y Teja, Ramón; Olimpiade la diaconessa; Col. Donne d’Oriente e d’Occidente; Milán; 1997.
}

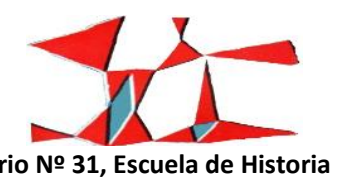


habitantes de Neocesarea, lugar de origen de su abuela Macrina senior. El texto dice así: "¿Qué prueba más clara podría haber en favor de nuestra fe que el hecho de haber sido educado por una abuela que era una bienaventurada mujer, salida de entre vosotros? Me refiero a la noble Macrina..., que nos ha educado en los dogmas de la devoción cuando aún éramos niños muy pequeños (Basilio de Cesarea, ep., 204, 6) ${ }^{59}$.

g) En los conflictos eclesiásticos también mediaron las mujeres, en grupo o individualmente, lográndolo en multitud de ocasiones. Teodoreto de Ciro describe un episodio en que las esposas de los cargos públicos en Roma y de los honorati acudieron ante Constancio II para pedirle que les devolviera al papa Liberio, desterrado a Tracia por el emperador al negarse a firmar la condena contra Atanasio de Alejandría en el concilio de Milán del 355. Se presentaron ante el emperador ataviadas con sus mejores galas para hacer ver su origen noble y ser tratadas con respeto. Como consecuencia de esas protestas, Liberio pudo volver a su sede ${ }^{60}$.

h) Otro testimonio del enorme poder que llegaban a ejercer algunas mujeres se produjo en el contexto del cisma donatista, que afectó a las provincias del África romana. En los primeros años del siglo IV la admiración de los cristianos por sus mártires se convirtió en un culto exagerado, contraviniendo incluso las normas de las autoridades eclesiásticas. Ceciliano, obispo de Cartago, criticó tales manifestaciones de piedad y se granjeó así el odio de una poderosa mujer, Lucila, que tenía la costumbre de besar el hueso de un mártir antes de comulgar. En su elección episcopal Ceciliano se encontró con la fuerte oposición de un grupo de eclesiásticos, liderado por Donato, que dio nombre al famoso cisma. En ese conflicto Donato contó con el apoyo de Lucila; los donatistas declararon nula la consagración de Ceciliano en un sínodo celebrado en Cartago y eligieron en su lugar a Mayorino, servidor de esa intrigante mujer y su candidato favorito ${ }^{61}$. Así pues, la influencia de esa mujer en la deposición de un obispo y la elección de otro fue extraordinaria.

De todo lo expuesto hasta ahora se deduce que la participación femenina en la política eclesiástica fue un hecho indiscutible, pero no se produjo de forma generalizada, sino restringida a algunos grupos, y

\footnotetext{
${ }^{59}$ Courtonne, Yves; Saint Basile. Correspondance; 2 vols.; ed. \& tr,; París; 1957 y 1961.

60 Teodoreto, Historia Eclesiástica, II, 17, 1-7.

61 Optato de Milevi, Tratado contra los donatistas, I, 18, 3
}

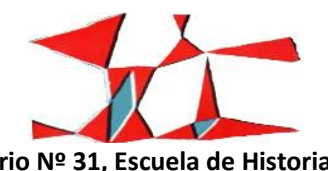




\section{EL PROTAGONISMO DE LAS MUJERES EN EL IMPERIO ROMANO. DEL POLITEÍSMO TRADICIONAL AL MONOTEÍSMO CRISTIANO}

extensiva a cierto número de mujeres con nombre propio, pues la normativa de la Iglesia y la opinión de sus autoridades establecía fuertes restricciones al acceso de las mujeres.

\section{Consideraciones finales}

Tras este recorrido por el Mundo antiguo hemos constatado que, pese a la transformación del derecho durante la época imperial con respecto a la equiparación femenina, la sociedad continuó mirando con desprecio y suspicacia a las mujeres emancipadas, situación que solo se podían permitir las más cultas y ricas.

Se ha podido comprobar también que algunas mujeres influyeron de manera determinante en el gobierno del Imperio, pero, debido a la falta de reconocimiento legal para intervenir en política y en los virilia officia, lo hicieron mediante una participación indirecta, la manera más habitual, por otra parte, de ejercer su poder las mujeres.

Las fuentes nos informan de que durante el Imperio la cultura entre las mujeres fue en aumento, pues aprovecharon la posibilidad de instruirse y cultivarse intelectualmente para participar en actividades hasta entonces típicamente masculinas. Pero observamos que la instrucción era un derecho exclusivo de las clases privilegiadas, y fundamentalmente de ámbito urbano, pues las mujeres humildes y de ambientes rurales no tenían esas posibilidades.

Así mismo, hemos llegado a la conclusión de que la posición de las mujeres en el plano religioso fue muy similar tanto en las religiones politeístas como en el cristianismo. Su colaboración en los cultos religiosos paganos apenas tuvo reconocimiento oficial, pero en la realidad se evidenció su carácter de complementariedad y su extraordinaria influencia en las diversas facetas. Por otra parte, un número importante de mujeres participaron en los cultos de las religiones mistéricas, que ayudaron a dignificar la condición de la mujer.

Con la llegada del cristianismo se dieron algunos pasos para avanzar en un proceso de equiparación con los hombres, pero la asimilación de la organización eclesiástica con las estructuras del Estado supuso una vuelta a los valores tradicionales y a la supeditación femenina. A pesar de ello, las mujeres intervinieron

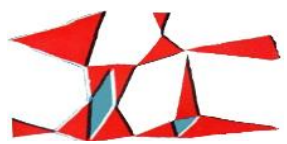

Anuario № 31, Escuela de Historia 
activamente en la política eclesiástica y resultaron determinantes en cuestiones trascendentales para la Iglesia.

\section{Bibliografía}

Alexander, Monique; "Immagini di donne ai primi tempi della cristianità", en Georges Duby-Michelle Perrot (eds.); Storia delle donne in Occidente. L'Antichità ; Roma-Bari; 1990; pp. 465-513.

Ash, James L.; "The Decline of Ecstatic Prophecy in the Early Church"; Theological Studies 37; 1976; 227-252.

Aspegren, Kerstin; The Male Woman. A Feminine Ideal in the Early Church; Uppsala Women'Studies/Women in religion 4; 1990.

Aubert, Marie- Josèphe; Des femmes diacres. Un nouveau chemin pour l'Èglise; París; 1987; p. 69 y pp. 75-77.

Aubin, Melissa; "More apparent than real? Questioning the difference in marital age between Christian and non-Christian women of Rome during the third and fourth centuries"; Ancient History Bulletin 14; 2000; pp. 1-13.

Barcellona, Rossana; "Le vedove cristiane tra i Padri e le norme"; en Johannes Grohe, Jerónimo Leal \& Vito Reale (eds.); I Padri e le scuole teologiche nei concili; Atti del VII Simposio Internazionale della Facoltà di Teologia; Ciudad del Vaticano; 2006; pp. 181-199.

Beard, Mary; "Re-Reading Vestal Virginity", en Richard Hawley \& Barbara Levick (eds.); Women in Antiquity: New Assessments; Routledge; Londres; 1995; pp. 166-177.

Bremmer, Jan; "Pauper or patroness: The widow in the early Christian Church"; en Idem \& Laurens Van den Bosch (eds.); Between Poverty and the Pyre: Moments in the History of Widowhood; Londres-Nueva York; 1995; pp. 31-57.

Bruno Siola, Rosa B.; "Viduae e coetus viduarum nella chiesa primitiva e nella norma dei primi imperatori cristiani"; en Atti dell'Accademia romanistica costantiniana. VIII Convegno internazionale; Nápoles; 1990; pp. 367-426.

Bybee, Ariel E.; "From Vestal Virgin to Bride of Christ: Elements of a Roman Cult in Early Christian Asceticism"; Studia Antiqua 1, 1; 2001.

Caldwell, Lauren; Roman Girlhood and the Fashioning of Femininity; Cambridge University Press; 2015.

Cantalemassa, Raniero (ed.); Etica sessuale e matrimonio nel cristianesimo delle origini; Milán; 1976; Sargenti, Manlio; "Matrimonio cristiano e società pagana"; Studia et Documenta Historiae et luris 51; 1985; pp. 367391.

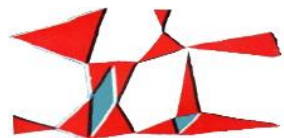




\section{EL PROTAGONISMO DE LAS MUJERES EN EL IMPERIO ROMANO. DEL POLITEÍSMO TRADICIONAL AL MONOTEÍSMO CRISTIANO}

Cantarella, Eva; L'ambiguo malanno. Condizione e immagine della donna nell'antichità greca e romana; Roma; 1981; pp. 185-207.

Clark, Elisabeth; "Women and asceticism in Late Antiquity: The refusal of gender and status"; en Vincent L. Wimbush \& Richard Valantasis (eds.); Asceticism; Nueva York; 1995; pp. 33-48.

Jerome, Chrysostome and Friends. Essays and Translations; Nueva York-Toronto 112; 1979.

Consolino, Franca Ela; "Modelli di santità femminile nelle più antiche Passioni romane"; Augustinianum 24; 1984; pp. 83-113.

"Modelli di comportamento e modi di santificazione per l'aristocrazia femminile d'Occidente"; en Andrea Giardina (ed.); Società romana e impero tardoantico; vol. l; Roma-Bari; 1986; pp. 273-306.

"La donna negli Acta Martyrum"; en Ugo Mattioli (ed.); La donna nel pensiero cristiano antico; Génova; 1992; pp. 95-117.

Crouzel, Henri; "Le mariage des chrétiens aux premiers siècles de l’Église"; Esprit et Vie 93; 1973; pp. 87-91.

Danielou, Jean; "Le ministére des femmes dans I'Église ancienne"; La Maison Dieu 61; 1960; pp. 70-96.

Davies, John Grant; "Deacons, deaconesses and the minor orders in the patristic period"; Journal of Ecclesiastical History 16; 1963; pp. 1-15.

Dossey, Leslie; "Wife beating and manliness in Late Antiquity"; Past and Present 199; 2008; pp. 2-40.

Duby, Georges y Perrot, Michel; Storia delle donne; P. Schmitt Pantel (ed.); L'Antichità; Roma; 1990; pp. 424462.

Elm, Susanna; "Virgins of God": The Making of Asceticism in Late Antiquity; Oxford; 1994; y Cooper, Kate; The Virgin and the Bride: Idealized Womanhood in Late Antiquity; Cambridge (MA); 1996.

Ferrari, Giuseppe; “Le diaconesse nella tradizione orientale”; Oriente Christiano 14; 1974; pp. 28-50.

Giannarelli, Elena; "La mulier virilis ed i suoi sviluppi eterodossi"; en Elena Giannarelli; La Tipologia femminile nella biografia e nell'autobiografia cristiana del IVo secolo; Roma; 1980; pp. 86-88.

"La rivalutazione della donna, la donna virile e la filosofia"; en Elena Giannarelli; S. Gregorio di Nissa. La vita di S. Macrina; intr., tr., y not.; Milán; 1988; pp. 30-41.

Gryson, Roger; Le ministère des femmes dans l'Église ancienne; Gembloux; 1972; pp.22-23.

Guiducci, Armanda; Perdute nella storia. Storia delle donne dal I al VII secolo d.C.; Florencia; 1989.

Haines-Eitzen, Kim; "Girls Trained in Beautiful Writing": Female Scribes in Roman Antiquity and Early Christianity"; Journal of Early Christian Studies 6, 4; 1998; pp. 629-646.

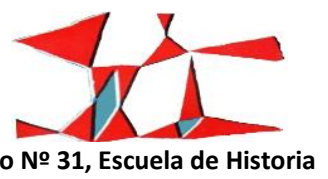

Anuario № 31, Escuela de Historia

Facultad de Humanidades y Artes (Universidad Nacional de Rosario), 2019

ISSN 1853-8835 
Hemelrijk, Emily A.; "The education of Women in Ancient Rome"; in W. Martin Bloomer (ed.); A Companion to Ancient Education, John Wiley \& Sons, Inc, Hoboken, NJ; 2015; pp. 292-304.

Holum, Kenneth H.; Theodosian Empresses. Women and Imperial Dominion in Late Antiquity; Berkeley; 1982.

Keener, Graig; "Women's Education and Public Speech in Antiquity"; Journal of the Evangelical Theological Society 50, 4; 2007; pp. 747-759.

Kraemer, Ross Shepard; Her Share of the Blessings. Women's Religions among Pagans, Jews and Christians in the Graeco-Roman World; Nueva York-Oxford; 1992.

Kramer, Ross Shepard \& D’Angelo, Mary Rose; Women and the Origins of Christianity; Londres; 1999.

Press; 2004. (eds.); Women's Religions in the Greco-Roman World. A Sourcebook; Oxford University

Lizzi, Rita; "Una società esortata al ascetismo: misure legislative e motivazioni economiche nel IV-V secolo d. C."; Studi Storici 30; 1989; pp. 137-138.

"Vergini di Dio - vergini di Vesta. Il sesso negato e la sacralità"; en Salvatore Pricoco; L'Eros difficile. Amore e sessualità nell'antico cristianesimo, Soveria Manelli, Rubbettino; 1998; pp. 89-132.

Madigan, Kevin y Osiek, Carolyne; Ordained Women in the Early Church. A Documentary History; Baltimore; 2005 (tr. esp. Teresa Arístegui Aguirre; ed. Verbo Divino; Estella (Navarra); 2006; pp. 31-49).

Mañas Núñez, Manuel; "Mujer y sociedad en la Roma imperial del siglo I"; Norba. Revista de Historia; vol. 16; 1996-203; pp. 191-207.

Marcos, Mar; Las mujeres de la aristocracia senatorial en la Roma del Bajo Imperio (312-410); Servicio de Publicaciones. Universidad de Cantabria; 1990.

"Le lettere di Giovanni Crisostomo a Olimpiade: Frammenti di un'amicizia"; en Ramón Teja; Olimpiade la diaconessa. Donne d'Oriente e d'Occidente; Milán; 1996; pp. 113-146.

"Mujer y profecía en el cristianismo antiguo", en Ramón Teja (ed.); Profecía, magia y adivinación en las religiones antiguas; Aguilar de Campóo (Palencia); 2001; pp.103-104.

Martimort, Aimé Georges; "A propos des ministéres feminins dans l'Église"; Bulletin de Littérature Ecclésiastique 74; 1973; pp. 103-108.

Les diaconesses: Essai historique; Roma; 1982; pp. 15-16.

Martínez Maza, Clelia; "Cristianas sabias, arquetipo femenino en el mundo tardoantiguo. Una aproximación historiográfica"; Revista de historiografía (RevHisto), no 22; 2015; pp. 83-100.

Mathews, John; Western Aristocracies and Imperial Court, A.D. 364-425; Oxford; 1975.

Mazzuco, Clementina; "E fui fatta maschio". La donna nel cristianesimo primitive; Turín; 1989.

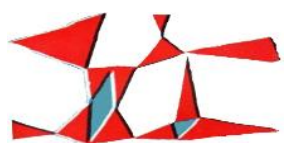

Anuario № 31, Escuela de Historia

Facultad de Humanidades y Artes (Universidad Nacional de Rosario), 2019

ISSN 1853-8835 


\section{EL PROTAGONISMO DE LAS MUJERES EN EL IMPERIO ROMANO. DEL POLITEÍSMO TRADICIONAL AL MONOTEÍSMO CRISTIANO}

"Figure di donne: la martire"; Atti del II Convegno nazionale di Studi sulla donna nel mondo antico; Turín; 1989; pp. 167-195.

Mekacher, Nina; Die vestalischen Jungfrauen in der römischen Kaiserzeit; Wiesbaden; 2006.

Melchor Gil, Enrique; "Mujeres y evergetismo en la Hispania romana”; en Juan Francisco Rodríguez Neila (ed.), Hispania y la epigrafía romana, cuatro perspectivas. Epigrafia e Antichità 26; Faenza; 2009; pp. 133178.

Metz, René; La consécration des vierges dans l'Église romaine. Étude d'histoire de la liturgie; París; 1954.

Munier, Charles; Mariage et virginité dans I'Église ancienne (ler-Ille siècle); Traditio Christiana 6; Berna; 1987.

Nazzaro, Antonio Vincenzo; "La vedovanza nel cristianesimo antico", Annali della Facoltà di Lettere e Filosofia della Università di Napoli 26; 1983-84; pp. 127-130.

"Figure di donne cristiane: la vedova"; en Renato Uglione (ed.); Atti del II convegno nazionale di studi su La donna nel mondo antico; Turín; 1989; pp. 197-219.

Osiek, Carolyne; "The Education of Girls in Early Christian Ascetic Traditions"; Studies in Religion / Sciences Religieuses 41(3); 2012; pp. 401-407.

Parker, Holt; Why Were the Vestals Virgins? Or the Chastity of Women and the Safety of the Roman State; AJPh 125; 2004; pp. 563-601.

Pau, Guy; L'émancipation fémenine dans la Rome Antique; Les Belles Lettres; París; 1978.

Pavón, Pilar; "La mujer en la religión romana: entre la participación y la marginación”; en Eduardo Ferrer Alveda, y Álvaro Pereira Delgado, (eds.); Hijas de Eva. Mujeres y religión en la Antigüedad; Sevilla; 2015; pp. 115-141).

(ed.), Marginación y mujer en el Imperio romano; Edizioni Quasar; Roma; 2018.

Pedregal, Amparo; “La mulier virilis como modelo de perfección en el cristianismo primitivo”; en Isabel Gómez Acebo (ed.); La mujer en los orígenes del cristianismo; Desclée de Brouwer; Bilbao; 2005; pp. 141-168.

Pietri, Charles; "Esquisse de conclusion. L'Aristocratie chètienne entre Jean de Constantinople et Augustin d’Hippone"; en Kannengiesser, Charles (ed.); Jean Chrysostome et Augustin; París; 1975; pp. 283-305.

Pomeroy, Sarah B.; Goddesses, Whores, Wives, and Slaves: Women in Classical Antiquity; Nueva York; 1975.

Raepsaet-Charlier, Marie-Thérèse; "Ordre sénatoriel et divorce sous le Haut-Empire romain: un chapitre de I'histoire des mentalités", ACD 17-18; 1981-1982; pp. 161-173.

"L'origine sociale des Vestales"; en Panayotis D. Dimakis (ed.); Mnémè G. A. Petropoulos II; Atenas; 1984; pp. 253-270.

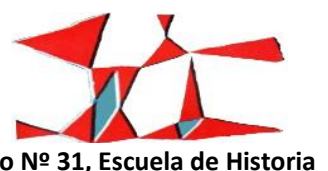

Anuario № 31, Escuela de Historia

Facultad de Humanidades y Artes (Universidad Nacional de Rosario), 2019 ISSN 1853-8835 
"Indispensables pero incapaces: las mujeres romanas en el Derecho y la Religión"; Annaeus 3; 2006; pp. 161-181.

"La place des femmes dans la religión romaine: marginalization ou complementarieté? L'apport de la théologie", en Pavón, Pilar (ed.); Marginación y mujer en el Imperio romano; Edizioni Quasar; Roma; 2018; pp. 201-219, p. 218.

Reynolds, Philip Lyndon; Marriage in the Western Church: The Christianization of Marriage during the Patristic and Early Medieval Periods; Leiden; 1994.

Robles, José Ma y Torres, Juana; “Epitafio de una esposa ejemplar: la Laudatio Turiae”; en Juana Torres (ed.); Historica et Philologica in honorem J. M. Robles; Universidad de Cantabria; 2002; pp. 15-27.

Rousselle, Aline; "La politica dei corpi: tra procreazione e continenza a Roma"; en Georges Duby-Michelle Perrot (eds.); Storia delle donne in Occidente. L'Antichità ; Roma-Bari; 1990; pp. 317-372, p. 335.

Ruether, Rosemarie Radford; "Mothers of the Church: Ascetic Women in the Late Patristic Age"; en Rosemarie Radford Ruether y Eleanor Mclaughlin (eds.); Women of Spirit. Female Leadership in the Jewish and Christian Traditions; Nueva York; 1979; pp. 29-70 y pp. 71-98.

Schade, Kathrin; Frauen in der Spätantike: Status und Repräsentation, eine Untersuchung zur römischen und frühbyzantinen Bildniskunst; Mainz; 2003.

Scheid, John; "Indispensabili «straniere». I ruoli religiosi delle donne a Roma"; en Georges Duby y Michel Perrot; Storia delle donne; P. Schmitt Pantel (ed.); L'Antichità; Roma; 1990; pp. 424-462).

"Les rôles religieux des femmes à Rome. Un complément", en Regula Frei-Stolba, Anne Bielman y Olivier Blanchi (eds.); Les femmes antiques entre sphere privée et sphere publique; Berna; 2003; pp. 137-151.

Schroeder, Joy A; "John Chrysostom's Critique of Spousal Violence"; Journal of Early Christian Studies 12/4; Johns Hopkins University Press; 2004; pp. 413-442.

Schüssler y Fiorenza, Elizabeth; "Word, Spirit and Power: Women in Early Christian Communities"; en Rosemary Ruether y Eleanor McLaughlin (eds.); Women of Spirit. Female Leadership in the Jewish and Christian traditions; Nueva York; 1979; pp. 29-70.

Sfameni Gasparro, Giulia; "Ruolo cultuale della donna in Grecia e a Roma: per una tipologia storico-religiosa"; en Ugo Mattioli (ed.); Donna e culture. Studi e documenti nel III anniversario della "Mulieris dignitatem"; Génova; 1991; pp. 57-121.

Sirago, Vito Antonio; Femminismo a Roma nel primo Impero; Roma; 1983.

Staples, Ariadne; From Good Goddes to Vestal Virgins: Sex and Category in Roman Religion; Routledge; Londres; 1998.

Takács, Sarolta A.; Vestal Virgins, Sibyls and Matrons. Women in Roman Religion; Universidad de Texas; 2008.

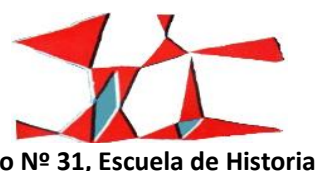




\section{EL PROTAGONISMO DE LAS MUJERES EN EL IMPERIO ROMANO. DEL POLITEÍSMO TRADICIONAL AL MONOTEÍSMO CRISTIANO}

Teja, Ramón; Olimpiade la diaconessa; Col. Donne d’Oriente e d’Occidente; Milán; 1997.

"Feminismo, religión y política en la Antigüedad tardía"; en Ramón Teja; Emperadores, obispos, monjes y mujeres. Protagonistas del cristianismo antiguo; Madrid; 1999; pp. 215-231.

Torjesen, Karen J.; When Women Were Priest. Women's Leadership in the Early Church and the Scandal of Their Subordination in the Rise of Christianity; San Francisco; 1995.

Torres, Juana; "Tipología femenina en las epístolas de San Basilio: Principios teóricos y manifestación práctica"; Studia Historica 4-5; 1986-87; pp. 227-234

La mujer en la epistolografía griega cristiana (ss. IV-V): tipología y praxis social; Servicio de Publicaciones. Universidad de Cantabria; 1990.

“Optima uxor/impudica et perversa mulier en la epistolografía griega cristiana (s. IV-V)"; Faventia 17; 1995; pp. 59-68.

"El tópico de las molestiae nuptiarum en la literatura cristiana antigua"; Studia Ephemeridis Augustinianum 50; La Narrativa cristiana antica. Codici narrativi, Strutture formali, Schemi retorici; XXIII Incontro di Studiosi dell'antichità cristiana Roma; 1995; pp. 101-115.

"El protagonismo de las primeras mártires cristianas"; en Isabel Gómez-Acebo (ed.); La Mujer en los orígenes del cristianismo; Madrid; 2005; pp.171-209.

“Minorías poderosas. Participación femenina en la política eclesiástica de los primeros siglos"; en Gonzalo Bravo y Raúl González Salinero (eds.); Minorías y Sectas en el Mundo romano; Signifer Libros; Madrid; 2006; pp. 93-105.

"Mulieres diaconissae. Ejemplos paradigmáticos en la Iglesia oriental de los ss. IV-V"; Diakonía, Diaconiae, Diaconato. Semantica e Storia nei Padri della Chiesa; Studia Ephemeridis Augustinianum 117; Roma; 2010; pp. 625-638

“Misoginia en la literatura patrística: Hacia una sistematización tipológica del ideal femenino"; en Juan José Pomer, Jordi Redondo y Ramón Torné (eds.); Misogínia, religió i pensament a la literatura del món antic i la seua recepció; Hakkert; 2013; pp. 243-271.

"Concerning John Chrysostom: Collectio Avellana 38 and his controversy in the West"; en Alexander Evers (ed.); Emperors, Bishops, Senators. The significance of the Collectio Avellana 367-553 AD; Peeters; (en prensa).

Treggiari,, Susan; Roman marriage. Iusti coniuges from the time of Cicero to the time of Ulpian; Oxford; 1993. Vagaggini, Cipriano; “L’ordinazione delle diaconesse nella tradizione greca e bizantina”; Orientalia Christiana Periodica 40; 1974; pp. 146-189.

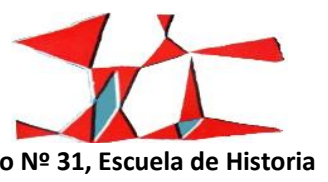

Anuario № 31, Escuela de Historia

Facultad de Humanidades y Artes (Universidad Nacional de Rosario), 2019 ISSN 1853-8835 
JUANA TORRES

Van Bremen, Riet; The limits of participation. Women and civic life in the Greek East in the Hellenistic and Roman periods; Amsterdam; 1996.

Van Ommeslaeghe, Florent; "Jean Chrysostome en conflict avec l'impératrice Eudoxie. Le dossier et les origines d'une légende"; Analecta Bollandiana 97; 1979; pp. 131-159.

Wildfang, Robin Lorsch; "The Vestal Virgins'Ritual Function in Roman Religion"; CM 50; 1999; pp. 227-234.

"The Vestals and annual public rites"; Clas. et Med. 52; 2001; pp. 223-256.

Recibido: 31 de julio de 2019 Aceptado: 27 de septiembre de 2019 Versión Final: 20 de octubre de 2019

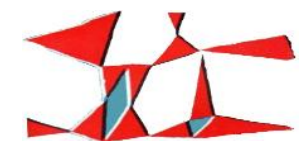


EL PROTAGONISMO DE LAS MUJERES EN EL IMPERIO ROMANO. DEL POLITEÍSMO TRADICIONAL AL MONOTEÍSMO CRISTIANO

Aceptado: 21 de junio de 2019

Versión Final:23 de septiembre de 2019 